\title{
The Cycle of Violence? \\ An Empirical Analysis of Fatalities in the Palestinian-Israeli Conflict
}

\author{
David A. Jaeger \\ College of William and Mary and IZA \\ M. Daniele Paserman \\ Hebrew University, IZA, and CEPR
}

College of William and Mary

Department of Economics

Working Paper Number 22

October 2005

\begin{abstract}
We thank Tatiana Slobodnitsky, Tamar Roth, Yaron Aronshtam, Eran Ben-Ari, and Lisa Andruyszyn for outstanding research assistance, Suhair Abdi and Yael Handelsman of B'Tselem for discussions about data as well as providing data on suicide bombings, Maj. Gen. (ret.) Netzach Mashiach for providing us the data on the separation barrier, and Noam Zussman for helpful comments and for providing us the data on assassination attempts. We also thank Joshua Angrist, Daniel Hamermesh, Stephen Cecchetti, Esteban Klor and seminar participants at IZA, CERGE-EI, the Max Planck Institute for Human Development, RWI-Essen, the Tinbergen Institute, Hebrew University, the ENS program at the Samuel Neaman Institute, Tel-Aviv University, the NBER Summer Institute, and the University of Wisconsin for comments on preliminary results. David Jaeger acknowledges financial support from the Alexander von Humboldt Stiftung and IZA. Daniele Paserman acknowledges financial support from the Samuel Neaman Institute at the Technion.
\end{abstract}


COLLEGE OF WILLIAM AND MARY

DEPARTMENT OF ECONOMICS

WORKING PAPER \# 22

October 2005

\title{
The Cycle of Violence? \\ An Empirical Analysis of Fatalities in the Palestinian-Israeli Conflict
}

\begin{abstract}
This paper studies the dynamics of violence in the Palestinian-Israeli conflict since the outbreak of the Second (or "Al-Aqsa") Intifada in September 2000, during which more than 3,300 Palestinians and more than 1,000 Israelis have been killed. The conflict has followed an uneven pattern, with periods of high levels of violence and periods of relative calm. Using data on the number of deaths occurring each day between September 2000 and January 2005, we estimate reaction functions for both Israelis and Palestinians and find evidence of unidirectional Granger causality from Palestinian violence to Israeli violence, but not vice versa. This finding is consistent whether we look only at the incidence of fatalities or whether we look at the level of fatalities, and is robust to the specification of the lag structure and the level of time aggregation. We find little evidence that violence on either side has a direct deterrent or incapacitation effect. We do find, however, that successful assassination attempts do reduce the number of subsequent Israeli fatalities. We conclude that, despite the popular perception that Palestinians and Israelis are engaged in "tit-for-tat" violence, there is no evidence to support that notion.
\end{abstract}

JEL Codes: C32, D71, D74, H56

Keywords: Intifada, terrorism, Granger causality

David A. Jaeger

Department of Economics

College of William and Mary

P.O. Box 8795

Williamsburg, VA 23187-8795

djaeger@wm.edu
M. Daniele Paserman

The Hebrew University of Jerusalem

Mount Scopus

Jerusalem, 91905

Israel

dpaserma@shum.huji.ac.il 
The most recent outburst of the Palestinian-Israeli conflict, commonly known as the Second, or "Al-Aqsa", Intifada, ${ }^{1}$ has claimed the lives of more than 3,300 Palestinians and more than 1,000 Israelis since its outbreak in September $2000 .^{2}$ This eruption of violence has been accompanied by a severe economic crisis, both in Israel and in the Palestinian Authorityadministered territories in the West Bank and Gaza. ${ }^{3}$ Repeated attempts to broker a stable ceasefire have failed, and the conflict has often been characterized as a vicious cycle of violence from which it is impossible to escape. ${ }^{4}$ This view suggests that the dynamics of the conflict are governed primarily by a vengeance motive, and that any act of violence will lead to a spiral of retaliation and counter-retaliation that cannot be broken. It is possible, however, that violence by one side may deter the opposite side from engaging in violence. Similarly, violence could also have an incapacitation effect. For example, military operations conducted by the Israel Defense Forces (IDF) against suspected terrorists and militants may lead to a reduction in violence, to the extent that they limit the operational capabilities of Palestinian groups to carry out attacks against Israeli targets. The question of whether military operations are effective and whether their timing is chosen appropriately has been at the center of the public debate in Israel, but little serious and convincing evidence has been provided to settle the issue.

\footnotetext{
${ }^{1}$ The term "intifada" literally means "shaking off" in Arabic, but it is most often and somewhat loosely translated as "uprising." The first intifada took place between 1987 and 1993. By and large, during the first intifada, Palestinians did not resort to the use of gunfire and explosives, drawing sympathy for their cause among international public opinion and in Israel. The first intifada ended in September 1993 with the Declaration of Principles, which marked the mutual recognition of Israel and the Palestine Liberation Organization, and the launch of the Oslo peace process.

${ }^{2}$ The figures for fatalities are current as of August 30, 2005.

${ }^{3}$ Israeli GDP per capita shrunk by about 6 percent in Israel between 2000 and 2002 in local currency terms, and by 19 percent in dollar terms (source: Bank of Israel). Palestinian Gross National Income per capita fell by 46 percent between 1999 and 2002 (The World Bank, 2003).

${ }^{4}$ For example, here are some reactions to the suicide bombing attack at the Dolphin disco in Tel Aviv on June 1, 2001. "U.N. Secretary-General Kofi Annan [...] condemns this indiscriminate terrorist attack [...]. This [...] event underlines the urgency of breaking the cycle of violence." (UN Secretary-General press release, June 1, 2001). "The Presidency of the European Union [...] appeals to Israel not to take measures which result in a further escalation of the cycle of violence." (European Union press release, June 2, 2001). The emphasis is ours.
} 
In this paper we explicitly address these issues by examining whether violence against Israelis and Palestinians affects the incidence and intensity of each side's reaction. We estimate how Palestinians react to targeted killings and Israeli violence against Palestinians in general, as well as Israel's response to suicide bombings and other Palestinian violence against Israelis. We test empirically whether the pattern of violence in the current conflict should indeed be characterized as a cycle, in which violence by one party causes violence by the other party and vice versa, or whether causality is unidirectional.

Using data on the daily number of deaths on both sides of the conflict from September 2000 to January 2005, we find that there is little evidence to suggest that both sides of the conflict react in a regular and predictable way to violence against them. Rather, we find that the direction of causality (in a Granger, 1969, sense) runs only from violence committed by Palestinians to violence committed by Israelis and not vice versa. That is, we find that the incidence and levels of Palestinian fatalities can be predicted by the past incidence and levels of Israeli fatalities, while there is little evidence that there is a direct relationship between fatal casualties suffered by the Palestinians and a lethal response. This finding is robust to the specification of the lag structure, the level of time aggregation, and holds throughout the different phases of the conflict. We find little evidence that violence on either side has a direct deterrent or incapacitation effect. We do find, however, that successful assassination attempts do reduce the number of subsequent Israeli fatalities.

Recent years have seen a flurry of research on the various aspects of terrorism and armed conflict in general, as well as specific to the Palestinian-Israeli conflict. A number of papers analyze terrorism as a tool to achieve political goals (Pape, 2003; Kydd and Walter, 2002.) Berrebi and Klor (2004) model the interaction between Palestinian militant groups and the Israeli 
political system, and test the predictions of their model using data on public opinion polls and Israeli terrorism fatalities since 1991. One empirical branch of the literature investigates the effects of terrorism on a number of different outcomes, such as macroeconomic aggregates (Eckstein and Tsiddon, 2004), foreign direct investment (Abadie and Gardeazabal, 2005), or financial markets (Abadie and Gardeazabal, 2003; Berrebi and Klor, 2005). A different set of studies has looked instead at the individual and aggregate determinants of terrorism (Berrebi, 2003; Krueger and Maleckova, 2003; Krueger and Laitin, 2003; Berman, 2003).

More closely related to our work is that of Enders and Sandler (1993), who examine the effectiveness of antiterrorism policies in the context of transnational terrorism. BrophyBaermann and Conybeare (1994) build a theoretical model that describes the optimal level and modality of retaliation against terrorism. In a recent paper, Zussman and Zussman (2005) attempt to assess the effectiveness of Israel's policy of targeted killings of terrorist leaders in the current conflict by looking at the reaction of the Israeli stock market. Our paper contributes to this literature by looking directly at the dynamic pattern of violence in the Palestinian-Israeli conflict.

In the next section of the paper we present a brief chronology of the second Intifada. In Section II we describe the data and present some descriptive statistics about the individuals who have been killed on both sides of the conflict. We then briefly discuss how violence by both sides may affect future levels of violence through a combination of revenge, deterrence and incapacitation motives, as well as our estimation framework. Section IV presents our basic estimates of the Israeli and Palestinian reaction functions. These are examined more closely in the following section on the role of assassinations of Palestinians and suicide attacks against Israelis. In Section VI, we discuss and interpret our findings, and in the last section we offer some conclusions. 


\section{Chronology}

On Thursday, September 28, 2000, Ariel Sharon, at that time the Israeli opposition leader and a staunch opponent to Palestinian statehood, made a heavily escorted visit to the Temple Mount in Jerusalem. Palestinians saw this visit to one of the holiest places in Islam as a political provocation. The following day, a large crowd of Palestinian demonstrators gathered on the Temple Mount at the end of the Friday prayers and confronted the Israeli police, throwing stones at policemen in the vicinity of the Western Wall. According to the U.S. Department of State (2000), "the Israeli police used rubber bullets and live ammunition to disperse the demonstrators, killing four people and injuring about 200." According to the Israeli government, fourteen policemen were injured during these incidents. ${ }^{5}$ Over the next following days, several similar demonstrations took place in the West Bank and the Gaza Strip. Thus began what has become known as the Second, or Al-Aqsa, Intifada, which has since claimed the lives of more than 3,300 Palestinians and more than 1,000 Israelis. $^{6}$

We identify seven distinct phases in the nearly five-year conflict, from its inception in September 2000 until mid-January 2005, when Mahmoud Abbas assumed the Presidency of the Palestinian Authority after the death of Yasser Arafat. These phases are characterized by differences in the intensity and the character of the violence. Although this classification is somewhat arbitrary, we believe that it captures many important features of the conflict.

The first phase of the conflict ran from the outbreak of violence in September 2000 until the February 2001 Israeli elections, which saw the fall of the Labor-led coalition government headed by Ehud Barak and the installment of a national unity government led by Likud leader

\footnotetext{
${ }^{5}$ Mitchell et al., (2001).

6 "Al-Aqsa" refers to the Al-Aqsa Mosque on the Temple Mount in Jerusalem.
} 
Ariel Sharon. ${ }^{7}$ The violence began as a series of confrontations between the Israeli security forces and Palestinian demonstrators, but it quickly evolved into a wider array of violent actions and responses (Mitchell et al., 2001). It is important to note that during this period channels of communication between the Israeli government and the Palestinian Authority remained open, with the two sides attempting to negotiate a cessation of violence and resume final status talks.

The second phase of the conflict coincided with the first several months of the Sharon government, from February to September 2001. This period saw the continuation of the diplomatic effort by the United States and other parties to broker a ceasefire and to resume final status talks. The report of the Sharm-el-Sheikh Fact Finding Committee led by United States Senator George Mitchell (2001), released in April, urged both sides to "immediately implement an unconditional cessation of violence," to rebuild confidence between the sides, and to resume negotiations. Although both sides adopted the recommendations of the report in principle, violence on both sides did not end. A second attempt at a ceasefire, outlined in a plan released in June 2001 by U.S. director of the Central Intelligence Agency, George Tenet, also failed to curb the violence. After this second attempt, the international community progressively decreased its diplomatic involvement.

We mark the beginning of the third phase of the conflict on September 11, 2001. According to several observers, the attacks on New York City and Washington, DC gave the Israeli government a "green light" to pursue more proactive measures against militant and terrorist groups, including incursions into the Palestinian-administered Territories. Among the

\footnotetext{
${ }^{7}$ In the Israeli political landscape, the left-of-center Labor Party is committed to a two-state solution to the Palestinian-Israeli conflict. The right-of-center Likud party puts more emphasis on security issues, and has traditionally adopted a vague stance with respect to the final status of the Territories. In the 2003 elections, its campaign was based on the statement that Israel would be willing to make "painful concessions" in exchange for peace. The eventual decision by Ariel Sharon to withdraw from the Gaza Strip has been met by strong opposition within the Likud party.
} 
measures adopted by the Israeli government was the confinement of Palestinian Authority President Yasser Arafat to his Ramallah headquarters, in December 2001. ${ }^{8}$ This third phase saw an escalation of violence on both sides, which culminated in March 2002. Palestinians were able to carry out 8 deadly suicide bombings inside Israel in this month alone, and the total death toll among Israelis climbed to over 100. At the same time, Israeli incursions inside Palestinian cities claimed the lives of close to 250 Palestinians. On March 27, 2002, a Palestinian suicide bomber entered the Park Hotel in the Israeli coastal city of Netanya, killing 28 Israelis gathered to celebrate Passover. As a response to this attack and the escalating violence of the previous month, the Israeli government launched "Operation Defensive Shield" (ODS), a large-scale military offensive against the Palestinian militant and terrorist infrastructure in the West Bank.

Operation Defensive Shield and its aftermath mark the fourth phase of the conflict, characterized by intense fighting in the West Bank between the IDF and the Palestinians. Following intense international pressure, Israel gradually withdrew its forces from major Palestinian population centers. The operation officially ended on May 10. However, the continuing suicide bombings inside Israel led the Israeli government to launch a second offensive in the West Bank, "Operation Determined Path", on June 20, 2002. In this second operation, Israeli forces encountered little resistance from the Palestinians. With international public opinion relatively muted, Israel has maintained its presence in all the major West Bank cities up to February 2005, when, as a result of the Sharm-el-Sheikh summit between Ariel Sharon and Mahmoud Abbas, it agreed to gradually transfer security control of the cities to the Palestinian Authority.

\footnotetext{
${ }^{8}$ Arafat was not allowed to leave his compound until October 2004, when, suffering from terminal illness, he was transferred to Paris, where he died on November 11.
} 
Two other important events occurred around this time: a) the beginning of construction of Israel's separation barrier in the north of Israel and around Jerusalem, on June 15, 2002, ${ }^{9}$ and b) President George W. Bush's Middle East speech on June 24, 2002, which called for a new Palestinian leadership and laid out Bush's vision for the long-term solution of the conflict. This speech marked the beginning of renewed U.S. diplomatic efforts to broker a ceasefire, and to move towards a negotiated settlement of the conflict. Later that year the United States was joined in its diplomatic efforts by the United Nations, the European Union, and Russia, who, on September 17, launched the "roadmap" for peace, a detailed three-phased plan for the implementation of Bush's vision. We take the Bush speech of June 24 as the beginning of the fifth phase of the conflict.

In early 2003, pressure was brought upon Palestinian Authority President Yasser Arafat to appoint the moderate Mahmoud Abbas as Prime Minister. Arafat initially attempted to severely limit the power of the Prime Minister position, but eventually was forced to relinquish some degree of real control to Abbas. This paved the way for the United States to restart the longstalled peace process. In June, Abbas and Israeli prime minister Ariel Sharon agreed to begin implementing the road map to peace. Abbas convinced the leaders of the Hamas and the Islamic Jihad to pledge to a ceasefire, which went into effect on June 29, 2003.

The summer 2003 ceasefire represents the sixth phase of the conflict. While Palestinian violence did indeed drop dramatically, there were still isolated attacks against Israelis. On the other hand, the Israeli government, which did not see itself bound by the ceasefire, continued to

\footnotetext{
${ }^{9}$ The Israeli Government decided to erect a barrier separating Israel and the West Bank in order to prevent the uncontrolled entry of Palestinians into Israel. In most areas, the barrier is comprised of an electronic fence with dirt paths, barbed-wire fences, and trenches on both sides, at an average width of 60 meters. In some areas, a wall six to eight meters high has been erected in place of the barrier system. The total planned length of the barrier is 620 kilometers, of which 174 kilometers around large Israeli settlements in the West Bank are subject to further approval. As of May 2005, 213 kilometers had been completed, and 114 kilometers were under construction. A similar barrier surrounding Gaza was completed in 1994, prior to the beginning of the Second Intifada.
} 
target militants and terrorists planning attacks against Israel. The ceasefire was not comprehensive, as the Al-Aqsa Martyrs Brigades (the armed wing of the Yasser Arafat's Fatah movement) and other smaller Palestinian groups did not agree to it. On August 19, 2003, Hamas claimed responsibility for a large suicide bombing on a Jerusalem bus, which killed 23 people. This marked the end of the ceasefire, and the beginning of the seventh and most recent phase of the conflict. This phase has been similar in character to the fifth phase, with Israel maintaining its military pressure on the militant groups, and the Palestinians attempting to carry out attacks against military and civilian targets inside Israel and in the Territories. Among the notable events in this last period was a suicide attack in the port of Ashdod in March 2004, and the subsequent Israeli decision to target the political leadership of Hamas, which resulted in the targeted killings of Sheikh Ahmed Yassin, Hamas' spiritual leader, and Abdel-Aziz el-Rantisi, his successor, in April 2004. Also of note are two large-scale military operations conducted by Israel in the Gaza Strip, in May 2004 and in September-October 2004, which led to a large number of Palestinian fatalities. Our analysis ends on 15 January 2005, two months after the death of Yasser Arafat, when Mahmoud Abbas assumed the presidency of the Palestinian Authority.

\section{Data and Descriptive Statistics}

To construct the data on the daily series of fatal casualties in the Palestinian-Israeli conflict since September 2000, we rely primarily on the web site of B'tselem (http://www.btselem.org), an Israeli human rights organization. In its statistics section, the site records in detail every single fatal casualty (excluding suicide bombers) on both sides of the conflict during the second Intifada. The data includes information on the date and circumstances of the fatal wounding, the date of death, the age, gender and locality of residence of the victim, and whether the victim was 
a civilian or a member of the security forces. ${ }^{10}$ Among the advantages of this data set are its comprehensiveness and the symmetrical treatment of fatalities on both sides of the conflict, something that is unavailable in neither the official statistics compiled by the Israeli Ministry of Foreign Affairs or the Palestinian National Information Centre, nor in the unofficial statistics compiled by the Palestinian Red Crescent Society. More importantly, the information published by B'tselem is widely thought to be accurate and reliable. ${ }^{11}$

The B'tselem data also have some limitations. For example, B'tselem does not keep daily statistics on non-fatal casualties, preventing us from assessing more accurately the intensity of violence on both sides. In addition, for the majority of the sample period B'tselem makes no effort to report the combatant status of Palestinian or Israeli fatalities: as a result, members of militant Palestinian groups are always classified as civilians, while uniformed Israeli soldiers not on duty are always classified as security forces, regardless of whether they were actively involved in combat at the time of their fatal wounding. Nevertheless, we feel that these data are the best comprehensive and consistent source measuring violence on both sides of the conflict.

Table 1 presents the demographic distribution of fatalities on both sides of the conflict over the entire sample period, from September 29, 2000 to January 15, 2005. The Israeli count includes all civilians and members of the security forces killed during this period, either in Israel (within the 1948 borders) or in the Territories, as well as foreign civilians killed by

\footnotetext{
${ }^{10}$ For Palestinians, the distinction between civilians and members of the security forces is not very relevant, since armed members of militia groups are classified as civilians.

${ }^{11}$ From the B'tselem website: "B'Tselem has attained a prominent place among human rights organizations. In December, 1989 it received the Carter-Menil Award for Human Rights. Its reports have gained B'Tselem a reputation for accuracy, and the Israeli authorities relate to them seriously. B'Tselem ensures the reliability of information it publishes by conducting its own fieldwork and research, whose results are thoroughly cross-checked with relevant documents, official government sources, and information from other sources, among them Israeli, Palestinian, and other human rights organizations."
} 
Palestinians. ${ }^{12}$ The Palestinian count includes all civilians and members of the security forces, as well as foreign civilians killed by Israeli security forces and civilians. The number of Palestinian fatalities is more than three times as high as that of Israeli fatalities and the demographic distribution of fatalities differs considerably between the two sides. Close to one third of total Israeli fatalities were women, while the share among Palestinians is less than 5 percent. If we restrict our attention to civilians, the share of women killed rises to 40 percent among Israelis, while it stays unchanged for Palestinians. There are differences also in the age distribution of fatalities. Relative to Israelis, a larger share of Palestinian fatalities were children below the age of 17 (20 percent versus 11 percent; 22 percent versus 16 percent among civilians). On the other hand, Israelis suffered a proportionally higher share of fatalities among the adults and elderly (46 percent versus 23 percent overall; 61 percent versus 23 percent among civilians). These figures reflect the different strategies adopted by the two sides: Israel's declared policy is to target only members of militant and terrorist groups, while Palestinian groups such as the Hamas, the Palestinian Islamic Jihad, and the Al-Aqsa Martyrs Brigades have never hidden their position that attacks against military and civilian targets are equally legitimate.

Figure 1 shows the monthly number of fatal casualties over our sample period.. The figure is consistent with the chronology of the events described in the previous section. We observe a large imbalance between the number of Palestinian and Israeli fatal casualties in the first phase of the conflict. The second phase, characterized by international efforts to broker a ceasefire saw a reduction in the level of violence on both sides. The level of violence rose sharply on both sides during the third phase of the conflict, after the failure of the international community's

\footnotetext{
${ }^{12}$ The count does not include Israeli civilians killed in terrorist attacks outside of Israel's borders, such as the December 2002 attack at a hotel in Mumbasa, Kenya, for which Al Qaeda claimed responsibility. The count also does not include three Israeli civilians killed in a suicide bombing in Tel Aviv perpetrated by British nationals on April 30, 2003.
} 
mediation efforts, and up to Operation Defensive Shield. During the fifth phase, with the reoccupation of the major centers by the Israeli army, the number of Palestinian fatalities remained at a high level. The number of Israeli fatalities during this period appears to exhibit a slight downward trend, with a few substantial spikes due to major suicide bombings. The level of violence on both sides dropped to nearly zero during the summer 2003 ceasefire. As the ceasefire broke down, however, the number of Palestinian fatalities returned to its pre-ceasefire levels, while the number of Israeli fatalities continued to fall.

Table 2 presents the statistics on the total number and the daily rate of fatal casualties in the seven phases of the conflict described above. On the Israeli side, both the daily fatality rate and the daily incidence of fatalities rise throughout the first four phases of the conflict, and then fall. The fatality rate in the last period is nearly identical to that of the first period, while the daily incidence of fatalities is less than half that of the first period. This reflects a possible shift in strategy by the Palestinians from attacks using gunfire towards larger and deadlier suicide bombings, as documented in the Table 2. The shift may also be due to an increase in Israel's ability to thwart and defend itself against gunfire attacks.

On the Palestinian side, we observe more variability in the number of fatalities per day, with a peak of over four during Operation Defensive Shield and a low of 0.196 during the ceasefire. Unlike the Israeli fatality rate, the Palestinian fatality rate approaches its pre-Operation Defensive Shield level after the ceasefire. The daily incidence of fatalities also approaches its pre-Operation Defensive Shield average after the ceasefire. The distribution of methods used by Israel evolves unevenly over time. The share of Palestinians killed by sophisticated weaponry and in assassination attempts is generally higher in the post-ODS period relative to the pre-ODS period, with the exception of the first few months of the Sharon government (Phase 2). 


\section{Theoretical and Empirical Framework}

We contend that three main factors may induce a dynamic link between violent incidents on the two sides of the conflict. First, violence by one side can have an incapacitation effect, if it limits the other side's capability to react. For example, Palestinian attacks against the IDF may reduce its capacity to respond. More plausibly, perhaps, Israeli targeted killings of key Palestinian leaders might reduce Palestinians' ability to carry out further attacks against Israel; this is the stated Israeli rationale for such actions. ${ }^{13}$ Second, violence can have a deterrent effect, when one side refrains from using violence in fear of the other side's reaction. Finally, violence by one side can lead to a reaction by the other side through a vengeance effect, to the extent that one side wishes to dispense retribution in response to the fatal casualties it suffers.

Solving for a full dynamic and game-theoretic equilibrium of violent behavior based on these three motives is beyond the scope of this paper. Instead, we posit the existence of empirical reaction functions for both sides. Allowing for a time lag between action and reaction as well as other factors that may shift the reaction function yields, for the Israelis,

$$
\mathrm{Pal}_{t}=f_{i}\left(I s r_{t-1}, \ldots, I s r_{t-p}, \mathrm{Pal}_{t-1}, \ldots P a l_{t-p}, \mathbf{X}_{t}\right),
$$

and for the Palestinians,

$$
I s r_{t}=f_{p}\left(P a l_{t-1}, \ldots P a l_{t-p}, I s r_{t-1}, \ldots, I s r_{t-p}, \mathbf{X}_{t}\right)
$$

where $\mathrm{Pal}_{t}$ and $I s r_{t}$ represent Palestinian and Israeli fatalities, respectively, at time $t, p$ is the maximum number of lags that have a potentially non-zero effect, and $\mathbf{X}_{t}$ is a vector of structural variables that may shift the reaction function up or down or (if we were to add interactions between these variables and the lagged fatalities) change the parameters of the reaction function. Note that the dependent variable is fatalities of the opposite group. That is, for the Israeli

\footnotetext{
${ }^{13}$ Assassinations of undercover Israeli General Security Service agents can be a form of violence on the Palestinian side that has an incapacitation effect. There have been a small number of such incidents in the current conflict.
} 
reaction function the dependent variable is Palestinian fatalities, and vice versa. Our primary interest is the effect of "own" fatalities on fatalities of the opposite group.

To estimate the effect of Israeli violence on Palestinian violence and vice versa, we employ a vector autoregression (VAR) framework using the daily data from B'Tselem. Our basic specification is:

$$
\left(\begin{array}{c}
P a l_{t} \\
I s r_{t}
\end{array}\right)=\mathbf{A}_{0}+\mathbf{A}_{1}\left(\begin{array}{c}
P a l_{t-1} \\
I s r_{t-1}
\end{array}\right)+\ldots+\mathbf{A}_{p}\left(\begin{array}{c}
P a l_{t-p} \\
I s r_{t-p}
\end{array}\right)+\mathbf{B X}_{t}+\boldsymbol{\varepsilon}_{t}
$$

where the $\mathbf{A}_{\mathbf{j}}$ 's and $\mathbf{B}$ are matrices of coefficients, $\mathbf{X}_{\mathbf{t}}$ is a vector of exogenous variable, and $\varepsilon_{t}$ is the vector error term. We look at two different specifications of the VAR: in the first specification (the incidence specification), $P a l_{t}$ and $I s r_{t}$ are dummies for whether there were any Palestinian and Israeli fatalities on day $t$; in the second (the levels specification) $\mathrm{Pal}_{t}$ and $I s r_{t}$ are the total number of fatalities in day $t$. All models are estimated equation by equation with ordinary least squares and heteroskedasticity-consistent standard errors. ${ }^{14}$

This is inherently a reduced-form approach. Which of the three effects (incapacitation, deterrence, and vengeance) is dominant is an empirical question. We cannot estimate the magnitude of each effect, but instead estimate the net effect of all three. If the coefficients on the "own" fatality variables are negative, then the incapacitation and deterrence effects dominate while if they are positive then the vengeance effect is more important.

While the signs of the individual coefficients are of some interest, our primary focus is testing, overall, whether fatalities on one side of the conflict cause fatalities on the other side. That is, can we reasonably say that side A reacts to the actions of side B and vice versa? Our

\footnotetext{
${ }^{14}$ Estimating the model equation by equation is equivalent to assuming that the off-diagonal terms of $E\left(\varepsilon_{t} \varepsilon_{t}{ }^{\prime}\right)$ are equal to zero. Estimating the system jointly yields identical inferences. We have also estimated the models using a probit specification for the incidence regressions and zero-inflated Poisson specifications for the levels regressions reported below. This yielded no qualitative difference from the results presented here.
} 
main empirical tool for doing so is the Granger (1969) causality test. In a vector autoregression, a variable $X$ is said not to Granger-cause $Y$ if, conditional on lagged values of $Y$, lagged values of $X$ have no predictive power for the current value of $Y$. In practice, the Granger tests amounts to a test of the joint significance of the coefficients on lagged values of $X$ in a regression of $Y$ on lagged values of $Y$ and lagged values of $X$.

The primary issue is whether the Granger test can be given a true causal interpretation. This boils down to the standard exogeneity question: is the disturbance term in the equation for one's side fatalities correlated with past values of the opposite side's fatalities? While it is possible that there are factors that may induce a correlation between the regressors and the disturbance (e.g. an endogenous increase in Israeli preventive measures following an attack against Palestinians), it is the nature of the type of violence in this conflict that many of the realized fatalities are due to random elements. For example, did the suicide bomber enter a crowded or empty bus? Did the intended target of an assassination attempt sit in the front or the back of his car? Given these random factors, we suspect that endogeneity bias is unlikely to be quantitatively important for our results. ${ }^{15}$

\section{Results}

Before estimating the regressions defined above, we first present nonparametric impulse response functions for both sides. We define the empirical Israeli and Palestinian response functions, respectively, as

\footnotetext{
${ }^{15}$ It is possible that Granger causation runs in the opposite direction of true causation, especially with time series that reflect forward-looking behavior (e.g. stock prices Granger-cause dividends or Christmas cards Granger-cause Christmas). In our context, such forward-looking behavior could occur if the expected future level of violence on one side affected the other side's level of violence in the present. For example, if the Palestinians engaged in preemptive strikes in anticipation of an Israeli attack, then our finding of Palestinian violence Granger-causing Israeli violence would be incorrect. We view this scenario as fairly implausible.
} 


$$
\begin{aligned}
& I s r R F_{t}=\frac{\sum_{s: I_{s-t}>0} P_{s}}{\sum_{s: I_{s-t}>0} 1}-\frac{1}{T} \sum_{s} P_{s} \text {, and } \\
& P a l R F_{t}=\frac{\sum_{s: P_{s-t}>0} I_{s}}{\sum_{s: P_{s-t}>0} 1}-\frac{1}{T} \sum_{s} I_{s},
\end{aligned}
$$

where $P_{s}$ and $I_{s}$ are the number of Palestinian and Israeli fatalities on day $s$. In words, the Israeli empirical response function at time $t$ is the average number of Palestinian fatalities exactly $t$ days after a day in which there was at least one Israeli fatality, minus the unconditional mean of Palestinian fatalities over the entire period. The empirical Palestinian impulse response function is defined similarly.

We present the empirical impulse response functions with 95 percent confidence bands in Figures $2 \mathrm{a}$ and $2 \mathrm{~b}$ for the Israelis and Palestinians, respectively. The contrast between the two response functions is striking. The Israeli response function shows that the number of Palestinian fatalities is above the mean for the first 38 days after a day with Israeli fatalities and that this difference is statistically significant for the first 10 of those days. The Palestinian response is never statistically significant, although it is positive for 26 out of the first 31 days. The magnitude of the Israeli response, on average, is about 17 times larger than the Palestinian response for the first 10 lags and about 15 times larger for all 60 lags shown in the figures.

In Table 3 we present the coefficients of the Israeli reaction functions, estimated from a VAR model with fourteen lags. The first column presents results using the incidence of any Palestinian deaths as the dependent variable, with lagged values of the incidence of any Israeli and Palestinian deaths as the explanatory variables. The results indicate that the Israelis react in a statistically significant and regular way on the first and fifth days after a fatal Palestinian 
attack, with a 7.6 percent higher probability of any Palestinian fatalities on the first day, and a 6.7 percent higher probability on the fifth day after a fatal Palestinian attack. The lack of any negative and statistically significant coefficients suggests that Palestinian attacks do not have a net deterrent or incapacitation effect. While the pattern of reaction is of some interest, our primary focus is on the test of Granger causality, reported in the penultimate line of the table. We find clear evidence that the incidence of fatal Palestinian attacks Granger-causes an Israeli response leading to the death of Palestinians.

In the second column of Table 3 we add indicators for the days of the week and the seven periods described earlier (the initial period, that of Ehud Barak's government, is the reference period). We also add a variable indicating the cumulative length of the separation barrier dividing the West Bank from Israel. ${ }^{16}$ The patterns that emerge from these coefficients are (not surprisingly) consistent with those in Figure 2: in particular, there is a decline in the incidence of violence against Palestinians, relative to the first period, during the initial period of the first Sharon government as well as during the declared ceasefire in mid-2003. As in the model without these additional controls, we find higher probabilities of fatal Israel attacks in the Occupied Territories one, four, five and nine days after a fatal attack against Israelis. The inclusion of period dummy variables and the length of the separation barrier does not mitigate our finding of Granger causality from the incidence of fatal Palestinian attacks to the incidence of fatal Israeli attacks.

In the third and fourth columns of Table 3, we estimate the levels version of the VAR. Here we find that there is some variation in the magnitude of the Israeli response to Israeli fatalities. The most violent response comes 5 days after a Palestinian attack, with each Israeli

\footnotetext{
${ }^{16}$ This variable was constructed using detailed data on the dates of completed construction and the length of each segment of the separation barrier, provided by the Israeli Ministry of Defense.
} 
fatal casualty leading to 0.213 additional Palestinian fatalities. In Column 4 we find that there has been a substantial reduction in the magnitude of Israeli attacks since Operation Defensive Shield. As with the incidence regressions, we find that the level of Palestinian attacks against Israelis Granger-causes an Israeli response.

We present estimates of the Palestinian reaction function for both incidence and levels in Table 4. While we find some degree of serial correlation in the Palestinians' attacks on Israelis, we find no support for the hypothesis that Israel's actions Granger-cause a Palestinian response. Moreover, we estimate no negative and statistically significant coefficients and therefore find no evidence that Israeli attacks against Palestinians have a net short-term deterrent or incapacitation effect. It is interesting to note, however, that while the incidence of Palestinian attacks against Israelis has declined since Operation Defensive Shield, the daily average number of Israelis killed has increased (although not statistically significantly) since then. This result mirrors our findings from Table 2, in which we documented a shift in the balance of Israeli fatalities between shooting and suicide attacks, which typically yield a higher number of fatalities. We also find that the separation barrier has little effect on the probability and magnitude of deadly Palestinian attacks against Israelis, once the period effects are controlled for. ${ }^{17} \mathrm{We}$ are cautious about interpreting this finding as conclusive regarding the effectiveness of the barrier, however. It is possible that it will be effective in reducing Palestinian violence within Israel only when it is complete. It is also possible that more geographic detail on the location of the barrier and Israeli fatalities would affect our conclusions, but such an analysis is beyond the scope of this paper.

Taking the results of Tables 3 and 4 together, we find there is strong evidence that the Israelis react in a significant and predictable way to Palestinian violence against them, but that

\footnotetext{
${ }^{17}$ The coefficient on the separation barrier is negative and statistically significant in both the incidence and levels regression when we do not include the period dummy variables.
} 
there is no evidence that the Palestinians react to Israeli violence. This stands in contrast to the popular notion that the Israelis and Palestinians are engaged in a "tit-for-tat" cycle of violence.

Previous research (Stock and Watson, 1989) has shown that conclusions about Granger causality may be sensitive to the choice of the lag structure for the independent variables as well as the lagged values of the dependent variable. To examine this issue, we estimated the incidence and levels regressions that include the day-of-week and period indicators as well as the length of the separation barrier for a variety of combinations of 4, 7, 14, and 21-day lag structures. We present the $\chi^{2}$ statistics for the tests of Granger causality in these models in Table 5. We find no evidence that our conclusions regarding the lack of a Palestinian response to Israeli violence is sensitive to the choice of lag structure. We continue to find that Palestinian violence Granger-causes an Israeli response in all of the incidence specifications and in the levels specifications with 14 lags or fewer. Although we cannot reject the null hypothesis of no Granger causality in the specifications with 21 lags, it is well known that adding lags can reduce the power of the Granger test. ${ }^{18}$

It may be that using days as our unit of observation masks some broader features of the data, particularly for the Palestinians, and that our results are sensitive to the frequency at which we aggregate fatalities. The decentralized and factional nature of the Palestinian side may dictate longer or less regular response times that may not be captured at a daily frequency. To explore this possibility, in Table 6 we present Granger causality statistics from the Israeli and Palestinian reaction functions estimated at weekly, bi-weekly, and monthly frequencies. Because there is very little variation in incidence at these frequencies, we present only results for regressions using levels. We do not find a significant response by the Palestinians at any

\footnotetext{
${ }^{18}$ In these specifications the first 14 lags are always jointly significantly different from zero.
} 
frequency, lending weight to our finding that Israeli violence does not Granger-cause a Palestinian response. Using weekly data, we continue to find that Palestinian violence Grangercauses an Israeli response using models with both two weeks and four weeks of lags, although the model with two lags is only significant at the 10.1 percent level. While not shown in the table, the coefficient on the first week's lag is always substantially larger than the coefficient on the other week(s). At the bi-weekly frequency, we do not find a significant Israeli response, while we do find a significant response at the monthly frequency.

An alternative way of assessing the sensitivity of our results to the degree of time aggregation is to continue using daily incidence or levels of fatalities as the dependent variable, while using as regressors the sum (over days $t-1$ to $t-7$ and $t-8$ to $t-14$ ) of the lagged values of the fatality variables. This specification preserves the large number of observations available, while also providing a parsimonious specification that captures the essential features of the data. This is essentially a version of the regression with 14 daily lags in which we restrict the coefficients on the first seven lags to be equal and the coefficients on the second seven lags to be equal. Note that in the levels regression the right hand side variables represent the cumulative number of fatalities in the past two weeks, while in the incidence regressions, the regressors represent the number of days in the past week in which there was at least one deadly incident.

The results of this "smoothed" estimation are presented in the top panel of Table 7. All models include the period and day-of-week dummy variables as well as the length of the separation barrier. Not surprisingly, the results are extremely similar to those presented in Tables 3 and 4 . We continue to find that Israel has a strong reaction to violence against Israelis in the first (and second) week after the occurrence of Israeli fatalities while there is no evidence that Palestinians react to violence against them. We use this specification throughout the rest of the 
paper, although none of our results are sensitive to using the smoothed specification or one that uses two weeks of lagged daily variables.

In Table 2 we showed that there is substantial variation over time in the level of violence committed by both sides, and the time period dummies in the regressions of Tables 3 and 4 confirm this. It is also possible that the parameters of the reaction function have changed over time. To explore this, we estimate versions of the smoothed regressions allowing the parameters of the reaction function to vary by period. Because Operation Defensive Shield signaled a change in IDF policy and ushered in continuous IDF presence in the Occupied Territories, we divide the data into three periods: before, during, and after Operation Defensive Shield.

The results split by period are presented in Table 8 . Our conclusion regarding Grangercausation of Palestinian violence to Israeli violence holds for all three periods in both the incidence and the levels regression. In neither specification do we reject the null hypothesis that the coefficients are equal in all periods, even though it appears that the magnitude of the Israeli response is larger during Operation Defensive Shield. On the Palestinian side, there is little evidence that Israeli violence Granger-causes a Palestinian response in any of the periods, with the possible exception of the pre-ODS period in the levels regression, where the p-value on the Granger causality test is 0.108 . As with the Israeli regression, we never reject the hypothesis that the parameters are equal in all three periods. Despite the variation in the intensity of violence over the course of the conflict, it appears that the parameters of the two sides' response functions are constant over time.

We have also investigated whether there is a differential Israeli response by type and location of the fatalities. We found little evidence to suggest that the parameters of the Israeli reaction function were different depending on whether civilians or security forces were killed, or 
whether the fatalities occurred within Israel or in the Occupied Territories. Similarly, there was no evidence that Palestinians reacted differently to deaths of women and children versus adult men, or that they chose different targets in response to Israeli violence. These results are not reported here and are available upon request.

\section{Suicide Bombings and Assassinations}

Perhaps the most well-known feature of the Second Intifada has been the regular use of suicide bombings as a means of inflicting fatalities within Israel. At the same time, Israel has attempted a series of assassinations of leaders of Palestinian groups such as Hamas, Islamic Jihad, and the Al-Aqsa Martyr Brigades. In this section we examine whether the two sides react to these specific events in a different way than to fatalities inflicted by more conventional means. One of the advantages of this analysis is that for both types of events we can identify in the data both successful and unsuccessful attempts: this allows us to glean some information onto how the two sides react not only to realized levels of violence, but also to intended violence. In addition, both the timing and the success of a suicide or an assassination attempt depend to a large extent on random factors, strengthening the causal interpretation of the results.

We first examine how Israel has reacted to suicide attacks by the Palestinians. We obtained from B'tselem a file recording all Palestinian suicide bombers during the course of the second Intifada. A suicide bomber is defined as the person who carried the explosive device that caused his or her death, or was present in a car when it exploded. The data include information on all suicide bombers, regardless of whether they managed to inflict any fatalities on the Israeli side. We define a successful attempt as a suicide attack that resulted in at least one Israeli fatality. We then regress either the daily incidence of Palestinian fatalities or the daily number of 
Palestinian fatalities on the number of days (out of the past 14 days) with successful suicide attacks, the number of days with unsuccessful suicide attacks, and the number of days with Israeli fatalities that are not a result of a suicide attack. We control for smoothed lags of the dependent variable, the period and day of week indicators, and the length of the separation barrier. The results are presented in Table 9.

The incidence of Palestinian fatalities appears not to be affected by either successful or failed suicide attempts in the first week after the event, while there is some effect of successful attempts in the second week. On the other hand, the number of Palestinian fatalities increases significantly in the first week after a successful suicide attempt, while it is not affected by failed suicide attempts. These results suggest that Israel does not change its overall level of activity, but does increase the intensity of its military actions in response to successful suicide attempts.

We next consider the Palestinians' reaction to Israeli assassination attempts. Since the beginning of the Second Intifada, Israel has carried out more than one hundred assassination attempts, directed at both military and political targets of all ranks. We obtained the data on assassination attempts used by Zussman and Zussman (2005). Using data from four different sources (both Israeli and Palestinian), these authors have compiled a list of all assassination attempts carried out by Israel from September 2000 to 30 April 2004. The data record the date and circumstances of each assassination attempt, the identity and the organizational affiliation of the target, whether the target was killed, and the total number of fatalities caused by the assassination attempt. We define an attempt as successful if the target is killed. As in the previous table we regress either the daily incidence or the daily number of Israeli fatalities on the number of days (out of the past 14 days) with successful assassination attempts, the number of days with unsuccessful assassination attempts, and the number of days with Palestinian fatalities 
that are not the result of an assassination attempt. We control for smoothed lags of Israeli fatalities, the period and day of week indicators, and the length of the separation barrier.

Table 10 presents the results of these regressions when the dependent variable includes any type of Israeli fatality. We find that failed assassinations significantly raise the probability of Israeli fatalities in the first week after the attempt, while successful assassinations lower it ( $p$ value of 0.083 ). This pattern is reinforced when we look at the levels specification: successful assassination attempts have a large and statistically significant negative effect on the number of Israeli fatalities in the first week after the attempt, and a smaller (and insignificant) positive effect in the second week. By contrast, there seems to be no effect of failed attempts on the level of Israeli fatalities. The results on the effect of successful attempts suggest that assassinations do have an incapacitation effect and reduce the probability and magnitude of attacks against Israelis. In contrast, the results on failed attempts suggest that these raise the Palestinians' motivation to carry out attacks against any type of Israeli targets, without much consideration for the scale of the attack.

In Table 11, we probe deeper into this issue by looking separately at the effect of assassination attempts on Israeli fatalities in suicide attempts and on all other fatalities. The results broadly confirm our previous conjecture. Successful assassination attempts have a large and statistically significant negative effect on the incidence and the levels of Israeli fatalities in suicide bombings, while they do not affect the level of violence against other Israeli targets. Failed assassination attempts have only a marginally negative effect on suicide bombings and significantly increase the probability of attacks against other Israeli targets, but not their magnitude. 


\section{Discussion}

We have consistently found that Palestinian violence cannot be predicted by past Israeli violence. One potential explanation for this finding is that the Palestinians do try to react, but are unable to do so effectively because of Israeli countermeasures. For example, it is possible that Israel, anticipating a Palestinian reaction, steps up its preventive measures to thwart any possible Palestinian response. These can take the form of more frequent roadblocks, tighter restrictions on the movement of Palestinians within the Occupied Territories and from the Territories into Israel, and increased presence and alertness of the Israeli security forces in crowded areas. This scenario would imply that an important explanatory variable is omitted from the equation specifying Palestinian violence and it would therefore be incorrect to give a causal interpretation to the coefficients of the Palestinian reaction function.

To counter this concern, we would like to include some measure of Israeli alertness or vigilance in the Palestinian reaction functions. One possibility is to proxy for vigilance with data on restrictions to movement of Palestinian civilians at Israeli checkpoints throughout the Occupied Territories. The United Nations Office for Coordination of Humanitarian Affairs (OCHA) has compiled a series of verbal reports on restrictions to movement of Palestinians in the Occupied Territories and from the Occupied Territories to Israel. In particular, the "Weekly Briefing Notes" section on the OCHA website records, on a daily basis, whether there were any restrictions to the movement of Palestinians at each of 88 checkpoints in the West Bank and Gaza. We hand-coded the data, assigning to each checkpoint a value ranging from 1 (completely closed) to 5 (completely open). ${ }^{19}$ The data is available from October 1, 2003 up to the end of our sample period. We excluded checkpoints that appear in the OCHA reports for a total of less than

\footnotetext{
${ }^{19}$ In the Appendix we give some examples of how we transformed the verbal descriptions in the OCHA reports into a numeric scale.
} 
365 days, leaving a total of 45 checkpoints in our sample. ${ }^{20}$ We then calculated for each day the fraction of checkpoints that were completely closed, and used that as our measure of Israeli vigilance. We note that often a checkpoint was completely closed because of a "hot" security warning, leading us to believe that the measure we use is indeed a good proxy for Israeli vigilance. The average percentage of checkpoints that were completely closed was 15.6 percent, with a standard deviation of 5.6 percent.

In the first column of Table 12, we first present regressions of the fraction of checkpoints closed on lagged Palestinian and Israel fatalities. ${ }^{21}$ We find that checkpoint closings are positively associated with lagged Palestinian fatalities, meaning that Israel does impose tighter restrictions to the movement of Palestinians after it has inflicted a high number of Palestinian fatalities. This suggests that our constructed measure of border closings is not an unreasonable proxy for Israeli vigilance. Interestingly, we also find that lagged Israeli fatalities are strongly positively associated with closings, suggesting that to some extent Israel uses closings as a retaliatory measure against Palestinian violence.

In columns (3) and (5) we replicate our results on the Palestinian reaction functions from Table 7 for the period from 1 October 2003 to 15 January 2005, the period for which we have data on checkpoint closings. As in Table 7, none of the coefficients on lagged Palestinian fatalities is individually or jointly statistically significant in either the incidence or levels regressions. In columns (4) and (6) we add the closure variable to these regressions. In the incidence regressions we find that the closure variable is not statistically significant while in the levels regression it is, with more border closings somewhat surprisingly leading to more Israeli

\footnotetext{
${ }^{20}$ These are presumably the most important checkpoints in the Occupied Territories. Our results are not sensitive to using all 88 checkpoints, or only checkpoints in the West Bank, or only checkpoints on the border between the Territories and Israel.

${ }^{21}$ The results for the association of border closings and lagged incidence of Israeli and Palestinian fatalities are qualitatively similar and are available from the authors by request.
} 
fatalities. Our conclusion regarding the lack of Granger causality is not altered in any way, however, in either specification. While our border closing variable may not be a perfect measure of Israeli vigilance, we suspect that any potential endogeneity bias in our results is quite small and does not account for the lack of an estimated Palestinian response to Israeli violence.

What does, therefore, account for the differences in the estimated reaction functions of both sides? Both Israel and the Palestinians probably would like to react to violence by the opposite side, to satisfy a vengeance motive and to signal to the other side that violence is costly. There is obviously a marked asymmetry between the two sides, however, in terms of their decision making processes and the technology at their disposal. The Israeli Defense Force is highly organized and centrally commanded, meaning that Israel has the organizational, logistic and technological capabilities to inflict fatalities on the Palestinian side when it wishes. This can explain our finding that Israel reacts predictably to Palestinian violence, even though in most of our specifications we find no evidence of a short-term net deterrent effect of Israeli actions. It seems possible that Israeli actions did have a deterrent effect in the long run - the overall level of Palestinian violence has declined since peaking in 2002, partially because of self-imposed ceasefires declared by the Palestinian factions. The finding that Israel reacts only to successful suicide attacks suggests that the vengeance motive plays an important a role, with Israeli public opinion pressuring the government and the armed forces to take some action after the occurrence of Israeli fatalities on a large scale.

In contrast, it appears that Palestinian violence is difficult to predict with past Israeli actions. Part of this can probably be attributed to the technology available - the Palestinians have limited means, and carrying out attacks against Israel may require long planning and complex logistics. In addition, the ability of the Palestinians to respond in an organized, timely, 
and predictable way is hampered by the decentralized nature of the various groups (Hamas, Islamic Jihad, al Aqsa Martyr Brigades, etc.) who engage in attacks against Israelis.

It is also possible that the Palestinians choose to act in a deliberately unpredictable way. While the Palestinians do not rely solely on suicide attacks, these do account for a substantial fraction of Israeli fatalities. The effectiveness of these kinds of terror attacks in disrupting dayto-day Israeli life is greater if they are, to some extent, unpredictable. We must also consider the possibility that the Palestinians, who view the current status quo as severely oppressive, are motivated by factors other than revenge, deterrence, and incapacitation, and that resistance to the military occupation itself is the driving force behind Palestinian violence. One of the Palestinians' stated goals has been the withdrawal of Israelis from the Gaza Strip and the West Bank. Short-term and predictable responses to Israeli violence may not be necessary or even desirable in achieving these ends. Seen in this light, the recent withdrawal of Israeli settlements in Gaza might be viewed as a long-term outcome of violence against Israelis.

Finally, we want to quantify the overall, long-term effect of violence by one side on the other side's reaction. To do so, we calculate the simple impulse-response function implied by the regressions in levels presented in Tables 3 and 4, and then compute the cumulative number of fatalities on one side of the conflict due to one fatality on the opposite side. ${ }^{22}$ At 60 days after a fatality, each of the cumulative impulse response functions reaches a nearly steady state. We find that one Palestinian fatality raises the cumulative number of Israeli fatalities by 0.247 in the long run. In contrast, one Israeli fatality raises the number of Palestinian fatalities by 2.190 ,

\footnotetext{
${ }^{22}$ The simple impulse response function assumes that, in the vector moving average (VMA) representation of the system of equations, there is no immediate (contemporaneous) response by any of the two sides to an exogenous shock to violence by the opposite side. Given that we are using daily data, we view this assumption as reasonable. We have also calculated an orthogonalized impulse response function that assumes that Israel may respond simultaneously to Palestinian violence, but not vice versa, and the results are essentially unchanged.
} 
nearly a factor of ten greater than those caused by a Palestinian fatality. ${ }^{23}$ Moreover, while the cumulative number of Palestinian fatalities is statistically different from zero at every horizon, we cannot reject the null hypothesis that Palestinian fatalities inflicted by Israel have no effect on the cumulative level of violence. The ninety-five percent confidence band of the Palestinian reaction function indicates that one Palestinian fatality would induce at most 0.53 Israeli fatalities in the long run. Overall, there is little evidence in the data to suggest that the conflict can be characterized as a self-perpetuating cycle of violence.

\section{Conclusion}

Our results paint a consistent picture of the dynamics of violence between Israelis and Palestinians during the Second Intifada. We find strong evidence that Israel reacts in a predictable and significant way to fatal Palestinian attacks against Israelis, both in terms of the incidence and magnitude of subsequent Palestinian fatalities. The result is robust to the lag structure used, to the level of time aggregation, and it holds across different periods of the conflict. We also find that Israel does not react in a significant way to attempted violence, but only to realized violence.

There is little evidence to suggest that the Palestinians have a similar response to Israeli violence. With the exception of assassination attempts against leaders of Palestinian groups, we repeatedly find no significant relationship (either positive or negative) between Palestinian fatalities and the Palestinian response; this finding is not at all sensitive to the lag structure or frequency of data used. We do find that successful assassination attempts reduce the level and to some extent the probability of subsequent Israeli fatalities. These attempts appear to affect the

\footnotetext{
${ }^{23}$ The ten to one ratio is relatively invariant to the number of lags used in the regressions to generate the impulse response functions.
} 
probability and magnitude of Israeli fatalities due to suicide bombings more than they affect other Israeli fatalities.

We conclude that, despite the popular perception that Palestinians and Israelis are engaged in "tit-for-tat" violence, there is no evidence to support that notion. Rather, the Israelis react in a predictable and statistically significant way to Palestinian violence against them while Palestinian actions are not related to Israeli violence, either through revenge or deterrence. Our results suggest that a cessation of Palestinian violence against Israel may eventually lead to an overall reduction in the level of violence. 


\section{References}

Abadie, Alberto and Gardeazabal, Javier. "The Economic Costs of Conflict: A Case Study of the Basque Country." American Economic Review, 93(1), March 2003, pages 113-132.

Abadie, Alberto and Gardeazabal, Javier. "Terrorism and the World Economy." Mimeo., Harvard University, August 2005.

Berman, Eli. "Hamas, Taliban and the Jewish Underground: An Economist's View of Radical Religious Militias.” NBER Working Paper 10004, September 2003.

Berrebi, Claude. "Evidence about the Link between Education, Poverty and Terrorism among Palestinians.” IRS Working Paper 477, Princeton University, September 2003.

Berrebi, Claude and Klor, Esteban F. "On Terrorism and Electoral Outcomes: Theory and Evidence from the Israeli-Palestinian Conflict.” Mimeo., Hebrew University, October 2004.

Berrebi, Claude and Klor, Esteban F. "An Empirical Analysis of the Differential Effects of Terrorism across Industries.” Mimeo., Hebrew University, January 2005.

Brophy-Baermann, Bryan, and Conybeare, John A.C. "Retaliating Against Terrorism: Rational Expectations and the Optimality of Rules versus Discretion." American Journal of Political Science, 38(1), February 1994, pages 196-210.

Eckstein Zvi, and Tsiddon, Daniel. "Macroeconomic Consequences of Terror: Theory and the Case of Israel." Journal of Monetary Economics, 51(5), July 2004, pages 971-1002.

Enders, Walter and Sandler, Todd. "The Effectiveness of Antiterrorism Policies: A VectorAutoregression-Intervention Analysis." American Political Science Review, 87(4), December 1993, pages 829-844.

Granger, C.W.J. "Investigating Causal Relations by Econometric Methods and Cross-Spectral Methods," Econometrica, 37(3), August 1969, pages 424-438.

Kydd, Andrew and Walter, Barbara F. "Sabotaging the Peace: The Politics of Extremist Violence.” International Organization, 56(2), Spring 2002, pages 263-296.

Krueger, Alan B. and Laitin, David D. "Kto Kogo: A Cross-Country Study of the Origins and Targets of Terrorism." Princeton University mimeo., November 2003.

Krueger, Alan B. and Maleckova, Jitka. "Education, Poverty and Terrorism: Is There a Causal Connection?” Journal of Economic Perspectives, Fall 2003, 17(4), pages 119-144.

Mitchell, George J.; Demirel, Suleyman; Jagland, Thorbjoern; Rudman, Warren B., and Solana, Javier. Report of the Sharm-el-Sheikh Fact-Finding Committee, United States Government, April 2001. 
Pape, Robert A. "The Strategic Logic of Suicide Terrorism.” American Political Science Review, 97(3), August 2003, pages 1-19.

Sims, Christopher A. "Money, Income and Causality." American Economic Review, 62(4), September 1972, pages 540-552.

Stock, James H., and Watson, Mark W. "Interpreting the Evidence on Money-Income Causality." Journal of Econometrics, 40(1), January 1989, pages 161-181.

The World Bank. "Twenty-Seven Months - Intifada, Closures and Palestinian Economic Crisis: An Assessment." The World Bank West Bank and Gaza Office, Jerusalem, May 2003.

U.S. Department of State. Country Reports on Human Rights Practices - 2000 (Israel). Bureau of Democracy, Human Rights and Labor, February 2001.

Zussman, Asaf, and Zussman, Noam. "Assassinations: Evaluating the Effectiveness of a Counterterrorism Policy.” Mimeo., Cornell University, January 2005. 
Figure 1: Monthly Number of Fatalities

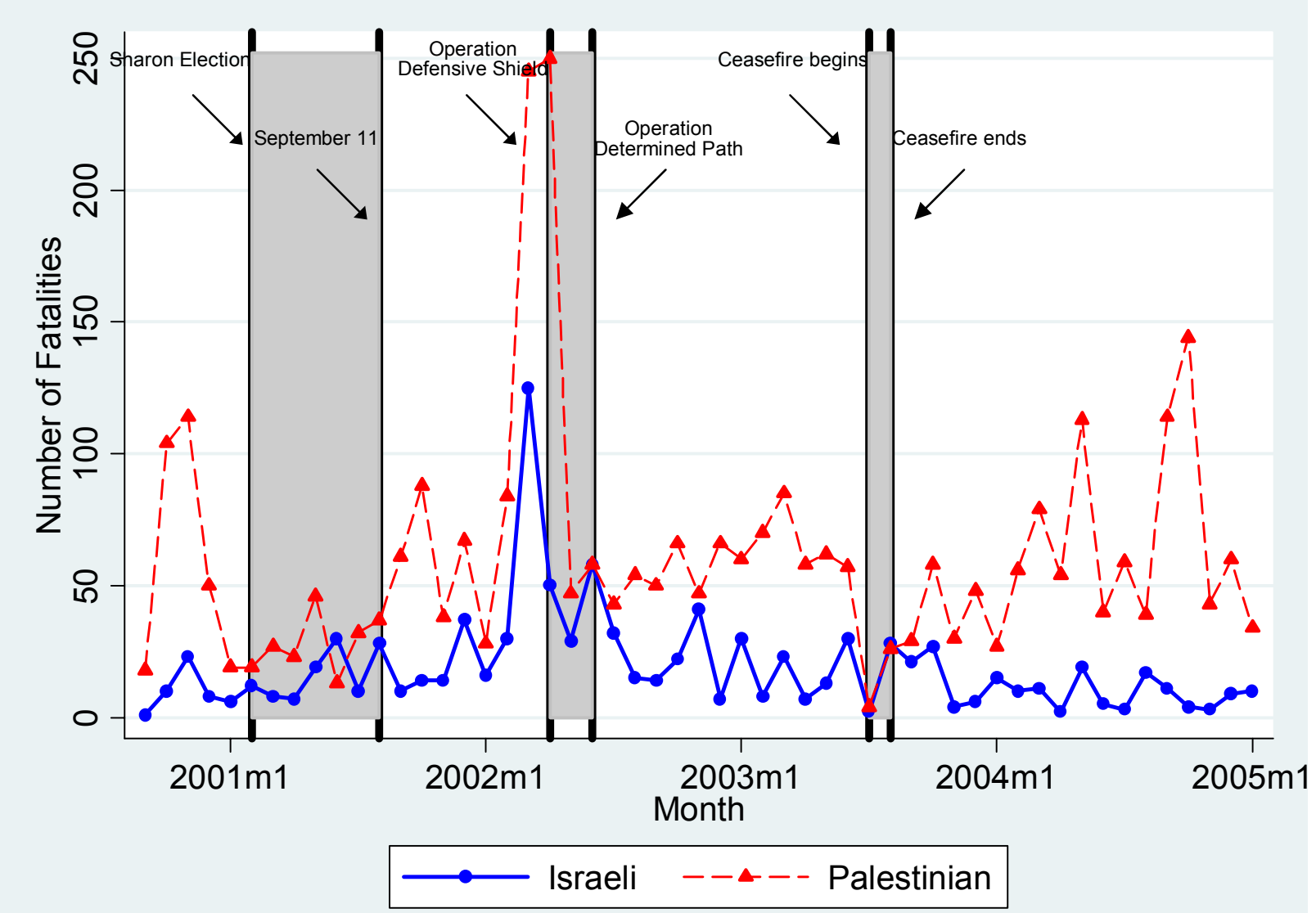

Source: Authors' calculations from B'Tselem data, from 29 September 2000 to 15 January 2005. 
Figure 2a: Empirical Israeli Response Function

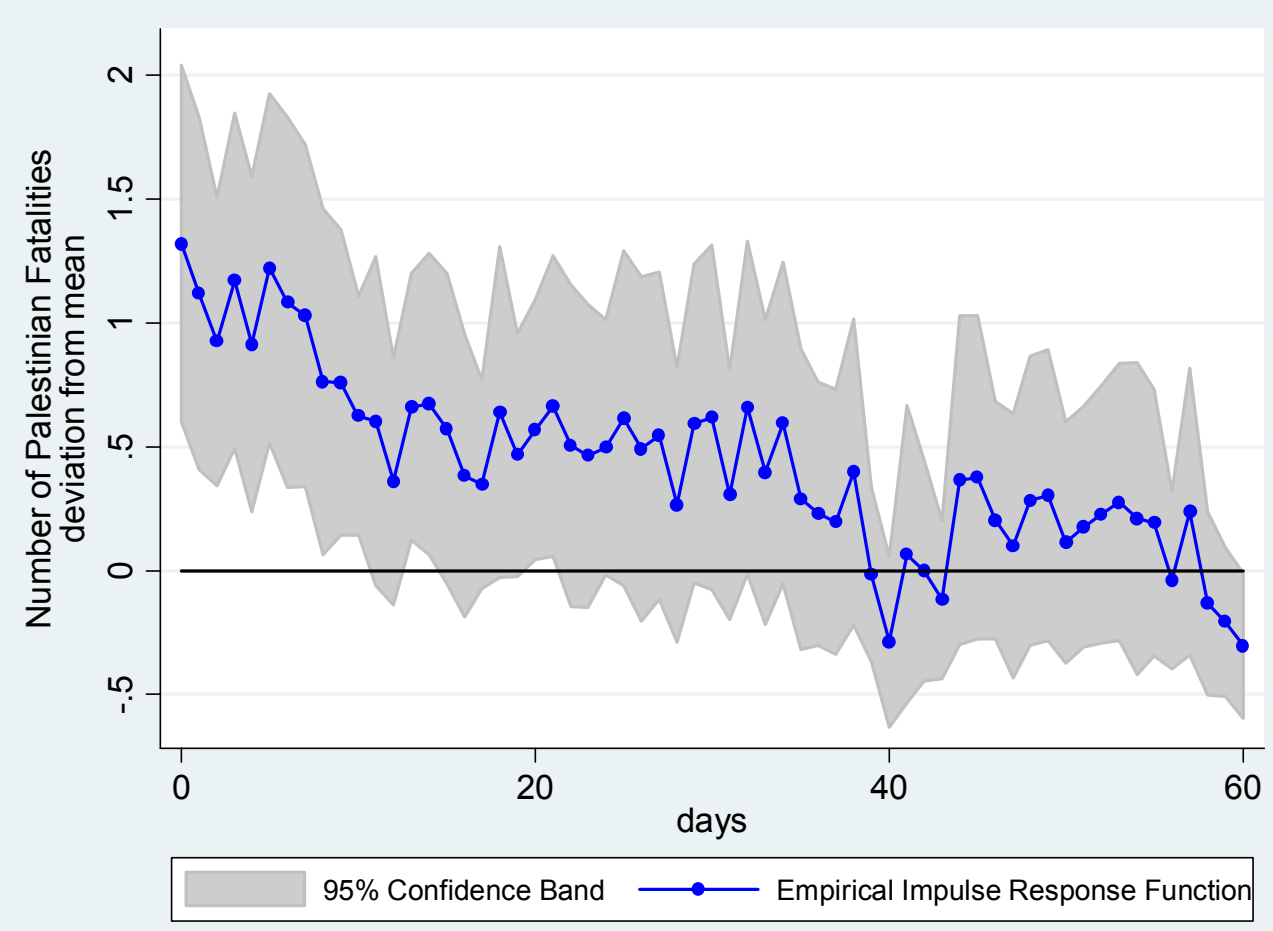

Source: Authors' calculations from B'Tselem data, from 29 September 2000 to 15 January 2005.

Figure 2b: Empirical Palestinian Response Function

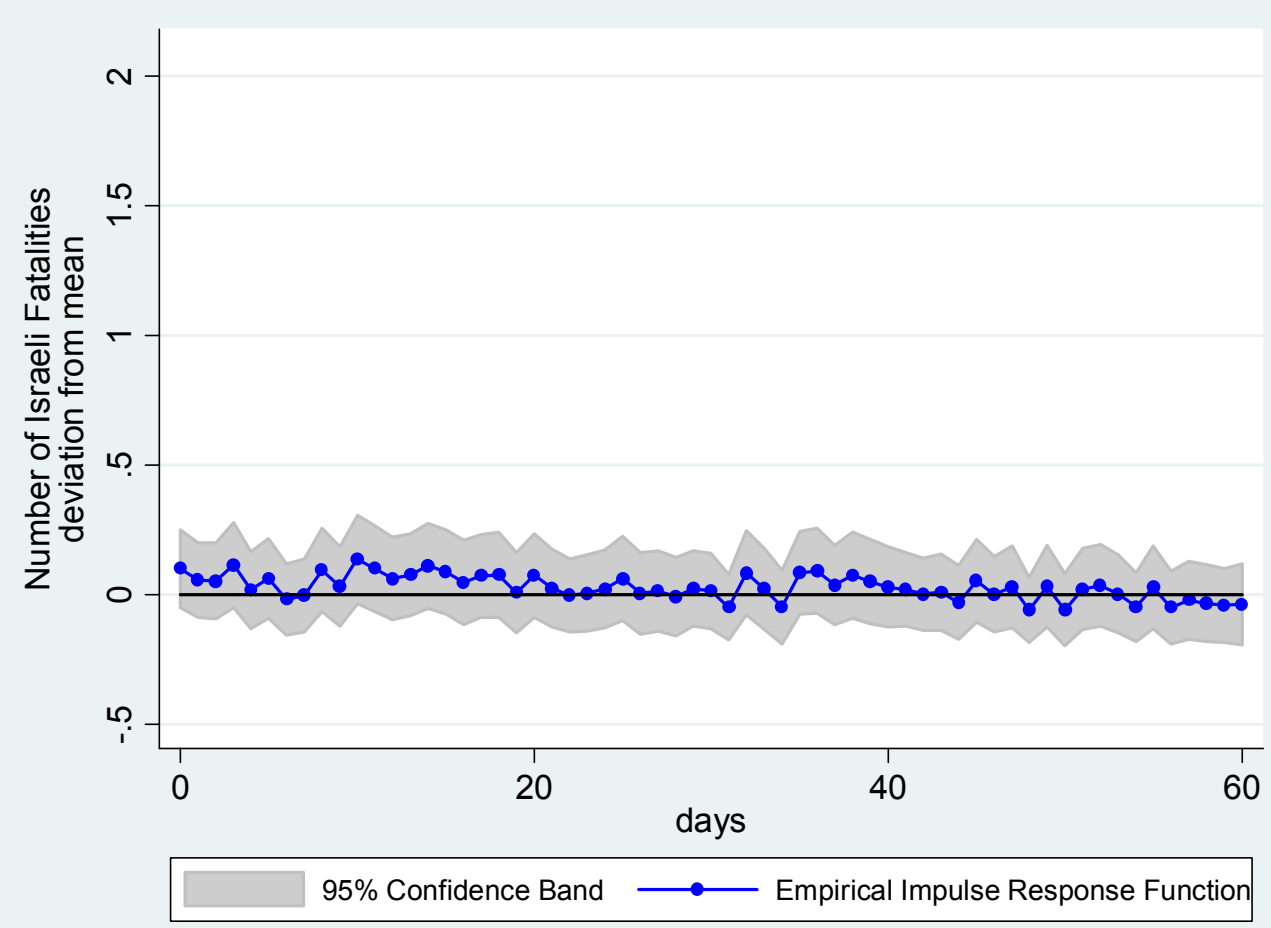

Source: Authors' calculations from B'Tselem data, from 29 September 2000 to 15 January 2005. 
Table 1

Demographic Distribution of Fatalities for Israelis and Palestinians

\begin{tabular}{|c|c|c|c|c|}
\hline & \multicolumn{2}{|c|}{ Israelis } & \multicolumn{2}{|c|}{ Palestinians } \\
\hline & $N$ & Share & $N$ & Share \\
\hline & \multicolumn{4}{|c|}{ All } \\
\hline Total Number of Fatalities & \multicolumn{2}{|c|}{994} & \multicolumn{2}{|c|}{3,244} \\
\hline Females & 310 & .312 & 157 & .048 \\
\hline \multicolumn{5}{|l|}{ Age } \\
\hline Children (0-17) & 109 & .110 & 636 & .196 \\
\hline Young Adults (18-23) & 303 & .305 & 1,019 & .314 \\
\hline Young Adults (24-29) & 117 & .118 & 747 & .230 \\
\hline Adults (30-59) & 356 & .358 & 689 & .212 \\
\hline Elderly (60 or older) & 102 & .103 & 50 & .015 \\
\hline \multirow[t]{2}{*}{ Age unknown } & 7 & .007 & 103 & .032 \\
\hline & \multicolumn{4}{|c|}{ Civilians } \\
\hline Total Number of Fatalities & \multicolumn{2}{|c|}{690} & \multicolumn{2}{|c|}{2,949} \\
\hline Females & 277 & .401 & 157 & .053 \\
\hline \multicolumn{5}{|l|}{ Age } \\
\hline Children (0-17) & 109 & .158 & 635 & .215 \\
\hline Young Adults (18-23) & 78 & .113 & 925 & .314 \\
\hline Young Adults (24-29) & 76 & .110 & 642 & .218 \\
\hline Adults (30-59) & 318 & .461 & 619 & .210 \\
\hline Elderly (60 or older) & 102 & .148 & 47 & .016 \\
\hline Age unknown & 7 & .010 & 81 & .027 \\
\hline
\end{tabular}

Note: The Israeli count includes all civilians and members of the security forces killed during this period, either in Israel (within the 1948 borders) or in the Territories, as well as foreign civilians killed by Palestinians. The Palestinian count includes all civilians and members of the security forces, as well as foreign civilians killed by Israeli security forces and civilians.

Source: Authors' tabulations of data from B'Tselem from 29 September 2000 to 15 January 2005. 
Table 2

Number and Daily Rate of Fatalities, Israelis and Palestinians, by Period

\begin{tabular}{|c|c|c|c|c|c|c|c|c|}
\hline & $\begin{array}{c}\text { Barak } \\
\text { Government }\end{array}$ & $\begin{array}{l}\text { Sharon Gov't } \\
\text { pre-9/11/2001 }\end{array}$ & $\begin{array}{c}\text { 9/12/2001- } \\
\text { ODS }\end{array}$ & $\begin{array}{c}\text { ODS- } \\
\text { Roadmap }\end{array}$ & $\begin{array}{c}\text { Roadmap- } \\
\text { Ceasefire }\end{array}$ & Ceasefire & $\begin{array}{c}\text { Post- } \\
\text { Ceasefire }\end{array}$ & TOTAL \\
\hline & $\begin{array}{c}29.9 .2000- \\
6.2 .2001\end{array}$ & $\begin{array}{l}\text { 7.02.2001- } \\
11.09 .2001\end{array}$ & $\begin{array}{l}12.09 .2001- \\
28.03 .2002\end{array}$ & $\begin{array}{c}29.03 .2002- \\
24.06 .2002\end{array}$ & $\begin{array}{l}25.06 .2002 \\
28.06 .2003\end{array}$ & $\begin{array}{c}29.06 .2003- \\
21.08 .2003\end{array}$ & $\begin{array}{c}22.08 .2003- \\
15.01 .2005\end{array}$ & $\begin{array}{c}29.09 .2000 \\
15.01 .2005\end{array}$ \\
\hline & (131 days) & (217 days) & (198 days) & (88 days) & (369 days) & (51 days) & (516 days) & (1570 days) \\
\hline & \multicolumn{8}{|c|}{ Israelis } \\
\hline Fatalities & 51 & 116 & 218 & 160 & 241 & 7 & 201 & 994 \\
\hline Fatalities/Day & .389 & .535 & 1.101 & 1.818 & .653 & .137 & .390 & .633 \\
\hline Daily Incidence of Fatalities & .237 & .212 & .318 & .341 & .187 & .098 & .107 & .190 \\
\hline Share by Gunfire & .764 & .379 & .423 & .275 & .432 & .286 & .289 & .407 \\
\hline \multirow[t]{2}{*}{ Share by Suicide Attacks } & .000 & .422 & .440 & .613 & .461 & .571 & .587 & .479 \\
\hline & \multicolumn{8}{|c|}{ Palestinians } \\
\hline Fatalities & 308 & 206 & 568 & 374 & 730 & 10 & 1,048 & 3,244 \\
\hline Fatalities/Day & 2.351 & .949 & 2.869 & 4.250 & 1.978 & .196 & 2.031 & 2.066 \\
\hline Daily Incidence of Fatalities & .664 & .479 & .672 & .830 & .650 & .137 & .609 & .610 \\
\hline Share by Gunfire & .929 & 680 & .754 & .850 & 699 & 600 & .676 & .739 \\
\hline Share by Helicopter, Aircraft or Tank Shellin & .052 & .277 & .151 & .099 & .221 & .200 & .306 & .210 \\
\hline Targeted Killings & .046 & .151 & .049 & .048 & .129 & .000 & .100 & .089 \\
\hline
\end{tabular}

Source: Authors' tabulations of data from B'Tselem from 29 September 2000 to 15 January 2005. 
Table 3

Daily Israeli Reaction Function, Incidence and Number of Fatalities

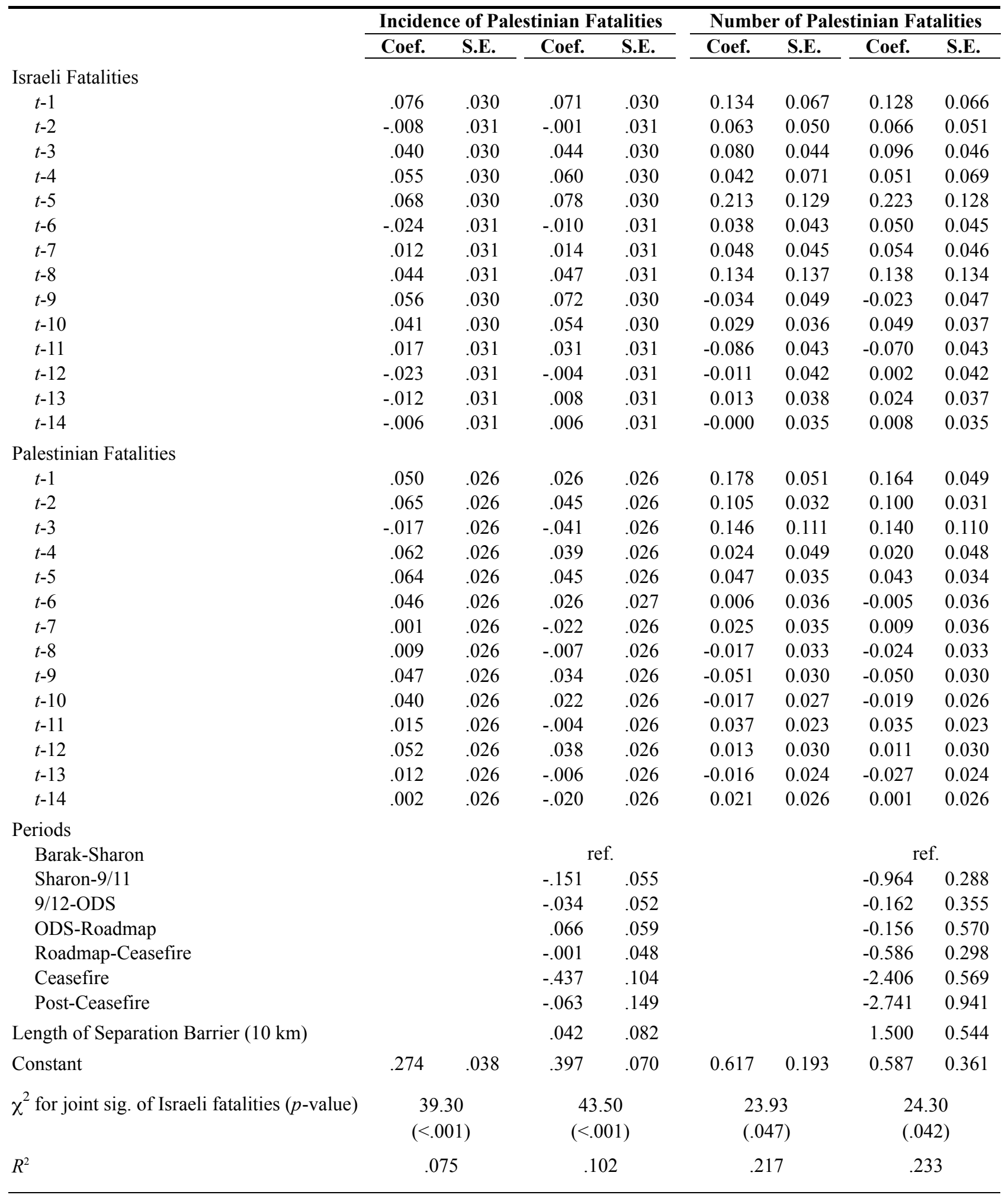

Note: Dependent variable is an indicator for any Palestinian fatalities in columns 1 and 2 and number of Palestinian fatalities in columns 3 and 4. The right hand side variables are indicators for whether there were any Palestinian/Israeli fatalities in days $t$ - 1 to $t-14$ (columns 1 and 2), and counts of Palestinian/Israeli fatalities in columns 3 and 4. Columns 2 and 4 also include day-of-week indicator variables. Heteroskedasticity-consistent standard errors.

Source: Authors' tabulations of data from B'Tselem from 29 September 2000 to 15 January 2005. 
Table 4

Daily Palestinian Reaction Function, Incidence and Number of Fatalities

\begin{tabular}{|c|c|c|c|c|c|c|c|c|}
\hline \multirow{3}{*}{ Palestinian Fatalities } & \multicolumn{4}{|c|}{ Incidence of Israeli Fatalities } & \multicolumn{4}{|c|}{ Number of Israeli Fatalities } \\
\hline & Coef. & S.E. & Coef. & S.E. & \multicolumn{2}{|c|}{$\begin{array}{ll}\text { Coef. } & \text { S.E. } \\
\end{array}$} & \multirow[t]{2}{*}{ Coef. } & \multirow[t]{2}{*}{ S.E. } \\
\hline & & & & & & & & \\
\hline$t-1$ & -.011 & .020 & -.009 & .020 & 0.023 & 0.019 & 0.026 & 0.020 \\
\hline$t-2$ & .020 & .020 & .022 & .020 & 0.023 & 0.024 & 0.027 & 0.024 \\
\hline$t-3$ & .007 & .021 & .006 & .021 & -0.003 & 0.016 & 0.000 & 0.016 \\
\hline$t-4$ & -.022 & .021 & -.023 & .021 & -0.016 & 0.018 & -0.009 & 0.017 \\
\hline$t-5$ & .030 & .021 & .031 & .021 & 0.014 & 0.030 & 0.014 & 0.029 \\
\hline$t-6$ & -.022 & .021 & -.027 & .021 & -0.008 & 0.020 & -0.011 & 0.021 \\
\hline$t-7$ & -.016 & .021 & -.020 & .021 & -0.029 & 0.016 & -0.029 & 0.016 \\
\hline$t-8$ & .010 & .021 & .012 & .021 & 0.062 & 0.024 & 0.064 & 0.023 \\
\hline$t-9$ & -.010 & .021 & -.009 & .021 & 0.003 & 0.022 & 0.005 & 0.022 \\
\hline$t-10$ & .007 & .020 & .004 & .021 & 0.006 & 0.021 & 0.009 & 0.021 \\
\hline$t-11$ & .012 & .021 & .008 & .021 & 0.008 & 0.018 & 0.012 & 0.018 \\
\hline$t-12$ & -.014 & .021 & -.014 & .021 & -0.024 & 0.013 & -0.026 & 0.013 \\
\hline$t-13$ & .013 & .020 & .006 & .020 & -0.014 & 0.018 & -0.020 & 0.018 \\
\hline$t-14$ & .023 & .020 & .016 & .021 & 0.030 & 0.024 & 0.027 & 0.024 \\
\hline \multicolumn{9}{|l|}{ Israeli Fatalities } \\
\hline$t-1$ & .068 & .027 & .055 & .027 & 0.086 & 0.034 & 0.072 & 0.033 \\
\hline$t-2$ & .058 & .027 & .046 & .027 & 0.004 & 0.020 & -0.012 & 0.021 \\
\hline$t-3$ & .025 & .027 & .014 & .026 & 0.024 & 0.021 & 0.008 & 0.021 \\
\hline$t-4$ & .021 & .026 & .009 & .026 & 0.042 & 0.045 & 0.026 & 0.044 \\
\hline$t-5$ & .058 & .028 & .047 & .028 & 0.003 & 0.016 & -0.013 & 0.017 \\
\hline$t-6$ & .038 & .027 & .026 & .028 & -0.005 & 0.025 & -0.021 & 0.027 \\
\hline$t-7$ & .051 & .027 & .030 & .028 & 0.011 & 0.028 & -0.013 & 0.029 \\
\hline$t-8$ & .024 & .026 & .015 & .026 & -0.010 & 0.017 & -0.024 & 0.016 \\
\hline$t-9$ & -.005 & .026 & -.015 & .026 & 0.011 & 0.023 & -0.006 & 0.023 \\
\hline$t-10$ & .068 & .028 & .058 & .028 & 0.023 & 0.026 & 0.010 & 0.025 \\
\hline$t-11$ & .027 & .026 & .019 & .026 & 0.013 & 0.023 & -0.001 & 0.023 \\
\hline$t-12$ & .029 & .026 & .022 & .027 & 0.009 & 0.015 & -0.007 & 0.016 \\
\hline$t-13$ & .009 & .026 & -.000 & .026 & 0.059 & 0.047 & 0.046 & 0.044 \\
\hline$t-14$ & .046 & .027 & .025 & .027 & 0.025 & 0.027 & 0.002 & 0.028 \\
\hline \multicolumn{9}{|l|}{ Periods } \\
\hline Barak-Sharon & \multicolumn{4}{|c|}{ ref. } & & & \multicolumn{2}{|c|}{ ref. } \\
\hline Sharon-9/11 & & & -.021 & .048 & & & 0.256 & 0.173 \\
\hline 9/12-ODS & & & .053 & .049 & & & 0.617 & 0.211 \\
\hline ODS-Roadmap & & & .053 & .064 & & & 1.168 & 0.437 \\
\hline Roadmap-Ceasefire & & & -.042 & .043 & & & 0.333 & 0.170 \\
\hline Ceasefire & & & -.155 & .088 & & & 0.619 & 0.518 \\
\hline Post-Ceasefire & & & -.187 & .112 & & & 1.390 & 1.054 \\
\hline Length of Separation Barrier (10 km) & & & .058 & .062 & & & -0.803 & 0.583 \\
\hline Constant & .076 & .032 & .092 & .059 & 0.293 & 0.091 & -0.082 & 0.162 \\
\hline \multirow[t]{2}{*}{$\chi^{2}$ for joint sig. of Palestinian fatalities ( $p$-value) } & \multirow{2}{*}{\multicolumn{2}{|c|}{$\begin{array}{c}7.89 \\
(.895)\end{array}$}} & \multirow{2}{*}{\multicolumn{2}{|c|}{$\begin{array}{c}7.80 \\
(.899)\end{array}$}} & \multirow{2}{*}{\multicolumn{2}{|c|}{$\begin{array}{l}15.73 \\
(.330)\end{array}$}} & \multirow{2}{*}{\multicolumn{2}{|c|}{$\begin{array}{l}17.50 \\
(.230)\end{array}$}} \\
\hline & & & & & & & & \\
\hline$R^{2}$ & \multicolumn{2}{|c|}{.051} & \multicolumn{2}{|c|}{.074} & \multicolumn{2}{|c|}{.041} & \multicolumn{2}{|c|}{.064} \\
\hline
\end{tabular}

Note: Dependent variable is an indicator for any Israeli fatalities in columns 1 and 2 and number of Israli fatalities in columns 3 and 4. The right hand side variables are indicators for whether there were any Palestinian/Israeli fatalities in days $t-1$ to $t-14$ (columns 1 and 2), and counts of Palestinian/Israeli fatalities in columns 3 and 4. Columns 2 and 4 also include day-of-week indicator variables. Heteroskedasticity-consistent standard errors. Source: Authors' tabulations of data from B'Tselem from 29 September 2000 to 15 January 2005. 
Table 5

Granger Causality Tests for Different Lag Structures

( $\chi^{2}$ statistics, $p$-values in parentheses)

\begin{tabular}{|c|c|c|c|c|}
\hline \multirow{2}{*}{$\begin{array}{l}\text { Lag Structure } \\
\text { (own, opposite) }\end{array}$} & \multicolumn{2}{|c|}{ Israeli Reaction Function } & \multicolumn{2}{|c|}{ Palestinian Reaction Function } \\
\hline & Incidence & Levels & Incidence & Levels \\
\hline$(4,4)$ & $\begin{array}{l}19.69 \\
(.001)\end{array}$ & $\begin{array}{c}9.95 \\
(.041)\end{array}$ & $\begin{array}{c}2.77 \\
(.598)\end{array}$ & $\begin{array}{c}3.04 \\
(.552)\end{array}$ \\
\hline$(7,4)$ & $\begin{array}{c}29.34 \\
(<.001)\end{array}$ & $\begin{array}{l}15.32 \\
(.032)\end{array}$ & $\begin{array}{l}7.62 \\
(.367)\end{array}$ & $\begin{array}{c}3.67 \\
(.817)\end{array}$ \\
\hline$(14,4)$ & $\begin{array}{c}53.15 \\
(<.001)\end{array}$ & $\begin{array}{l}23.22 \\
(.057)\end{array}$ & $\begin{array}{c}9.77 \\
(.779)\end{array}$ & $\begin{array}{l}17.54 \\
(.229)\end{array}$ \\
\hline$(21,4)$ & $\begin{array}{c}73.58 \\
(<.001)\end{array}$ & $\begin{array}{l}27.92 \\
(.142)\end{array}$ & $\begin{array}{l}16.58 \\
(.680)\end{array}$ & $\begin{array}{l}20.40 \\
(.496)\end{array}$ \\
\hline$(7,7)$ & $\begin{array}{c}27.21 \\
(<.001)\end{array}$ & $\begin{array}{l}15.32 \\
(.032)\end{array}$ & $\begin{array}{c}6.54 \\
(.478)\end{array}$ & $\begin{array}{c}4.91 \\
(.670)\end{array}$ \\
\hline$(14,7)$ & $\begin{array}{c}47.21 \\
(<.001)\end{array}$ & $\begin{array}{l}23.62 \\
(.051)\end{array}$ & $\begin{array}{c}8.54 \\
(.859)\end{array}$ & $\begin{array}{l}18.29 \\
(.194)\end{array}$ \\
\hline$(21,7)$ & $\begin{array}{c}66.07 \\
(<.001)\end{array}$ & $\begin{array}{l}27.57 \\
(.153)\end{array}$ & $\begin{array}{l}15.68 \\
(.736)\end{array}$ & $\begin{array}{l}21.01 \\
(.459)\end{array}$ \\
\hline$(14,14)$ & $\begin{array}{c}43.50 \\
(<.001)\end{array}$ & $\begin{array}{l}24.30 \\
(.042)\end{array}$ & $\begin{array}{c}7.80 \\
(.899)\end{array}$ & $\begin{array}{l}17.50 \\
(.230)\end{array}$ \\
\hline$(21,14)$ & $\begin{array}{c}58.72 \\
(<.001)\end{array}$ & $\begin{array}{l}27.69 \\
(.149)\end{array}$ & $\begin{array}{l}14.43 \\
(.808)\end{array}$ & $\begin{array}{l}20.98 \\
(.460)\end{array}$ \\
\hline$(21,21)$ & $\begin{array}{c}57.38 \\
(<.001)\end{array}$ & $\begin{array}{l}26.16 \\
(.200)\end{array}$ & $\begin{array}{l}14.48 \\
(.805)\end{array}$ & $\begin{array}{l}20.56 \\
(.486)\end{array}$ \\
\hline
\end{tabular}

Note: The entries in the table are the test statistics and $p$-values for the joint hypothesis that all lags of own fatalities are equal to zero. All models include period and day-of-week indicators as well as the length of separation barrier as regressors.

Source: Authors' tabulations of data from B'Tselem from 29 September 2000 to 15 January 2005. 
Table 6

Effect of Time Aggregation on

Granger Causality Tests: Levels

( $\chi^{2}$ statistics, $p$-values in parentheses)

\begin{tabular}{lcc}
\hline Frequency of Data & $\begin{array}{c}\text { Israeli } \\
\text { Reaction Func. }\end{array}$ & $\begin{array}{c}\text { Palestinian } \\
\text { Reaction Func. }\end{array}$ \\
\hline Weekly & & \\
2 Lags & 4.58 & 2.48 \\
& $(.101)$ & $(.289)$ \\
4 Lags & 9.19 & 2.74 \\
& $(.056)$ & $(.602)$ \\
Bi-Weekly & & \\
1 Lag & 0.04 & 1.42 \\
& $(.838)$ & $(.492)$ \\
2 Lags & 1.96 & 3.10 \\
& $(.162)$ & $(.212)$ \\
Monthly & & 1.04 \\
1 Lag & 3.83 & $(.309)$ \\
\hline
\end{tabular}

Note: The entries in the table are the test statistics and $p$-values for the joint hypothesis that all lags of own fatalities are equal to zero. All models include period and day-of-week indicators as well as the length of separation barrier as regressors.

Source: Authors' tabulations of data from B'Tselem from 29 September 2000 to 15 January 2005. 
Table 7

Smoothed Reaction Functions

\begin{tabular}{|c|c|c|c|c|}
\hline \multirow{2}{*}{$\begin{array}{l}\text { In days prior to day } t \text { : } \\
\text { Number of days with own fatalities (incidence) or } \\
\text { Number of own fatalities (levels) }\end{array}$} & \multicolumn{2}{|c|}{ Incidence } & \multicolumn{2}{|c|}{ Levels } \\
\hline & Coef. & S.E. & Coef. & S.E. \\
\hline \multicolumn{5}{|c|}{ Israeli Reaction Function (Palestinian Fatalities) } \\
\hline$t-1$ to $t-7$ & .038 & .010 & 0.113 & 0.033 \\
\hline$t-8$ to $t-14$ & .031 & .011 & 0.009 & 0.017 \\
\hline \multirow[t]{2}{*}{$\chi^{2}$ for sig. of own fatalities ( $p$-value) } & \multirow{2}{*}{\multicolumn{2}{|c|}{$\begin{array}{c}29.96 \\
(<.001)\end{array}$}} & \multirow{2}{*}{\multicolumn{2}{|c|}{$\begin{array}{l}11.43 \\
(.003)\end{array}$}} \\
\hline & & & & \\
\hline$R^{2}$ & \multicolumn{2}{|c|}{.085} & \multicolumn{2}{|c|}{.190} \\
\hline \multicolumn{5}{|c|}{ Palestinian Reaction Function (Israeli Fatalities) } \\
\hline$t-1$ to $t-7$ & -.003 & .007 & 0.004 & 0.005 \\
\hline$t-8$ to $t-14$ & .003 & .007 & 0.006 & 0.005 \\
\hline \multirow[t]{2}{*}{$\chi^{2}$ for sig. of own fatalities ( $p$-value) } & \multicolumn{2}{|c|}{0.25} & \multicolumn{2}{|c|}{2.56} \\
\hline & \multicolumn{2}{|c|}{$(.881)$} & \multicolumn{2}{|c|}{$(.278)$} \\
\hline$R^{2}$ & \multicolumn{2}{|c|}{.064} & \multicolumn{2}{|c|}{.041} \\
\hline
\end{tabular}

Note: Dependent variables are daily incidence of fatalities on opposite side or daily number of fatalities on opposite side. All models estimated with ordinary least squares and include lagged own smoothed lags, period and day-of-week indicators as well as the length of the separation barrier as regressors. Heteroskedasticity-consistent standard errors.

Source: Authors' tabulations of data from B'Tselem from 29 September 2000 to 15 January 2005. 
Table 8

Smoothed Reaction Functions: Before, During, and After Operation Defensive Shield

\begin{tabular}{|c|c|c|c|c|c|c|c|c|}
\hline \multirow{3}{*}{$\begin{array}{l}\text { In days prior to day } t \text { : } \\
\text { Number of days with own fatalities (incidence) or } \\
\text { Number of own fatalities (levels) }\end{array}$} & \multicolumn{4}{|c|}{$\begin{array}{c}\text { Israeli Reaction Function } \\
\text { (Palestinian Fatalities) }\end{array}$} & \multicolumn{4}{|c|}{$\begin{array}{c}\text { Palestinian Reaction Function } \\
\text { (Israeli Fatalities) }\end{array}$} \\
\hline & \multicolumn{2}{|c|}{ Incidence } & \multicolumn{2}{|c|}{ Levels } & \multicolumn{2}{|c|}{ Incidence } & \multicolumn{2}{|c|}{ Levels } \\
\hline & Coef. & S.E. & Coef. & S.E. & Coef. & S.E. & Coef. & S.E. \\
\hline \multicolumn{9}{|l|}{ Before Operation Defensive Shield } \\
\hline$t-1$ to $t-7$ & .042 & .014 & 0.082 & 0.036 & -.009 & .014 & 0.000 & 0.011 \\
\hline$t-8$ to $t-14$ & .032 & .017 & 0.035 & 0.026 & .004 & .012 & 0.017 & 0.009 \\
\hline \multicolumn{9}{|l|}{ During Operation Defensive Shield } \\
\hline$t-1$ to $t-7$ & .026 & .020 & 0.274 & 0.115 & -.024 & .042 & -0.014 & 0.016 \\
\hline$t-8$ to $t-14$ & .039 & .028 & 0.115 & 0.081 & -.001 & .041 & -0.010 & 0.012 \\
\hline \multicolumn{9}{|l|}{ After Operation Defensive Shield } \\
\hline$t-1$ to $t-7$ & .031 & .017 & 0.050 & 0.020 & .002 & .008 & -0.004 & 0.004 \\
\hline$t-8$ to $t-14$ & .025 & .017 & -0.013 & 0.013 & .001 & .008 & 0.001 & 0.005 \\
\hline$\chi^{\alpha}$ for sig. of own fatalities: Pre-ODS ( $p$-value) & 16.02 & $(<.001)$ & 7.52 & $(.023)$ & 0.53 & $(.769)$ & 4.46 & $(.108)$ \\
\hline$\chi^{2}$ for sig. of own fatalities: ODS ( $p$-value) & 9.41 & $(.009)$ & 5.97 & $(.051)$ & 0.37 & $(.829)$ & 0.98 & $(.612)$ \\
\hline$\chi^{L}$ for sig. of own fatalities: Post-ODS ( $p$-value) & 5.53 & $(.063)$ & 7.38 & $(.025)$ & 0.07 & $(.964)$ & 1.00 & $(.606)$ \\
\hline$\chi^{2}$ for test of equality of coefficients in all periods & 0.67 & $(.955)$ & 6.91 & $(.141)$ & 0.87 & $(.929)$ & 4.92 & $(.295)$ \\
\hline$R^{2}$ & \multicolumn{2}{|c|}{.644} & \multicolumn{2}{|c|}{.401} & \multicolumn{2}{|c|}{.249} & \multicolumn{2}{|c|}{.125} \\
\hline
\end{tabular}

Note: Dependent variables are daily incidence of fatalities on opposite side or daily number of fatalities on opposite side. All models estimated with ordinary least squares and include lagged own smoothed lags, period and day-of-week indicators as well as the length of the separation barrier as regressors. Heteroskedasticity-consistent standard errors.

Source: Authors' tabulations of data from B'Tselem from 29 September 2000 to 15 January 2005. 
Table 9

Smoothed Israeli Reaction Functions:

Reaction to Successful and Unsuccessful Suicide Attempts

\begin{tabular}{|c|c|c|c|c|}
\hline & \multicolumn{4}{|c|}{ Palestinian Fatalities } \\
\hline & \multicolumn{2}{|c|}{ Incidence } & \multicolumn{2}{|c|}{ Levels } \\
\hline & Coef. & S.E. & Coef. & S.E. \\
\hline \multicolumn{5}{|c|}{ Number of days with successful suicide attempts: } \\
\hline$t-1$ to $t-7$ & .001 & .022 & 0.608 & 0.263 \\
\hline$t-8$ to $t-14$ & .049 & .021 & 0.299 & 0.210 \\
\hline \multicolumn{5}{|l|}{ Number of days with failed suicide attempts: } \\
\hline$t-1$ to $t-7$ & -.007 & .027 & 0.137 & 0.162 \\
\hline$t-8$ to $t-14$ & .024 & .026 & 0.511 & 0.269 \\
\hline \multicolumn{5}{|l|}{ Number of days with other Israeli fatalities: } \\
\hline$t-1$ to $t-7$ & .045 & .011 & 0.526 & 0.112 \\
\hline$t-8$ to $t-14$ & .017 & .012 & -0.018 & 0.097 \\
\hline$\chi^{2}$ for sig. of successful attempts ( $p$-value) & 5.37 & $(.068)$ & 5.54 & $(.063)$ \\
\hline$\chi^{2}$ for sig. of failed attempts ( $p$-value) & 0.89 & $(.640)$ & 3.84 & $(.147)$ \\
\hline$\chi^{2}$ for sig. of other fatalities ( $p$-value) & 22.38 & $(<.001)$ & 22.46 & $(<.001)$ \\
\hline$R^{2}$ & \multicolumn{2}{|c|}{.088} & \multicolumn{2}{|c|}{.198} \\
\hline
\end{tabular}

Note: Dependent variable is daily incidence or the daily number of Palestinian fatalities. All models estimated with ordinary least squares and include "smoothed" lags of Palestinian fatalities, period and day-of-week indicators as well as the length of the separation barrier as regressors. Heteroskedasticity-consistent standard errors.

Source: Authors' tabulations of data from B'Tselem from 29 September 2000 to 15 January 2005. 
Table 10

Smoothed Palestinian Reaction Functions:

Reaction to Successful and Unsuccessful Assassination Attempts

\begin{tabular}{|c|c|c|c|c|}
\hline & \multicolumn{4}{|c|}{ Israeli Fatalities } \\
\hline & \multicolumn{2}{|c|}{ Incidence } & \multicolumn{2}{|c|}{ Levels } \\
\hline & Coef. & S.E. & Coef. & S.E. \\
\hline \multicolumn{5}{|c|}{ Number of days with successful assassination attempts: } \\
\hline$t-1$ to $t-7$ & -.022 & .013 & -0.218 & .069 \\
\hline$t-8$ to $t-14$ & .003 & .014 & 0.099 & .093 \\
\hline \multicolumn{5}{|c|}{ Number of days with failed assassination attempts: } \\
\hline$t-1$ to $t-7$ & .090 & .036 & 0.120 & .205 \\
\hline$t-8$ to $t-14$ & -.022 & .029 & -0.263 & .157 \\
\hline \multicolumn{5}{|l|}{ Number of days with other Palestinian fatalities: } \\
\hline$t-1$ to $t-7$ & -.002 & .008 & -0.022 & .042 \\
\hline$t-8$ to $t-14$ & -.001 & .008 & 0.093 & .052 \\
\hline$\chi^{2}$ for sig. of successful attempts ( $p$-value) & 3.06 & $(.217)$ & 10.09 & $(.006)$ \\
\hline$\chi^{2}$ for sig. of failed attempts ( $p$-value) & 7.14 & $(.028)$ & 4.66 & $(.097)$ \\
\hline$\chi^{2}$ for sig. of other fatalities ( $p$-value) & 0.08 & $(.959)$ & 3.48 & $(.176)$ \\
\hline$R^{2}$ & \multicolumn{2}{|c|}{.073} & \multicolumn{2}{|c|}{.048} \\
\hline
\end{tabular}

Note: Dependent variable is daily incidence or the daily number of Israeli fatalities. All models are estimated with ordinary least squares and include "smoothed" lags of Israeli fatalities, period and day-of-week indicators as well as the length of the separation barrier as regressors. Heteroskedasticity-consistent standard errors.

Source: Authors' tabulations of data from B'Tselem and Zussman and Zussman (2005) from 29 September 2000 to 30 April 2004. 
Table 11

Smoothed Palestinian Reaction Functions:

Suicide Attacks and Other Actions as Reaction to Successful and Unsuccessful Assassination Attempts

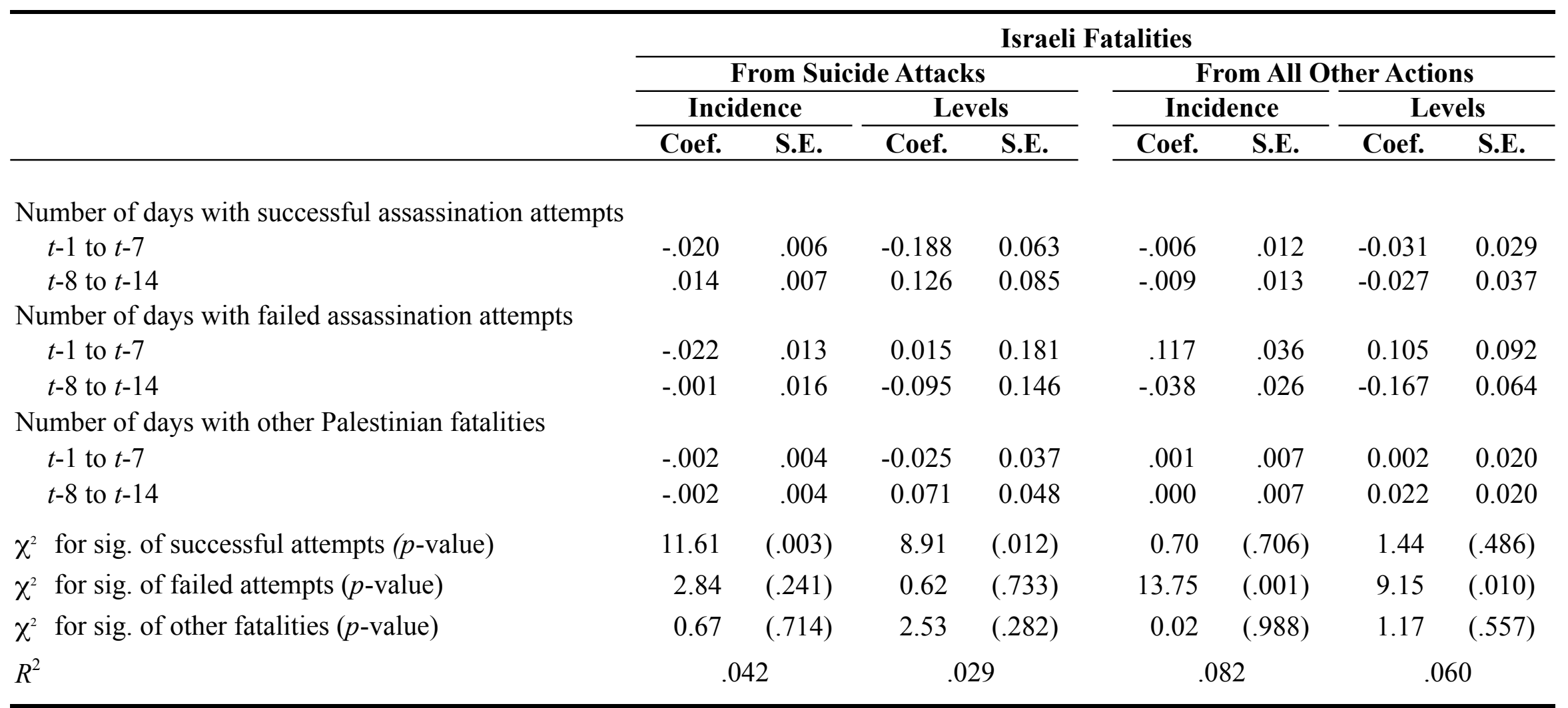

Note: Dependent variable is daily incidence or daily number of Israeli fatalities by suicide bombings or all other actions. All models estimated with ordinary least squares and include "smoothed" lags of Israeli fatalities, period and day-of-week indicators as well as the length of the separation barrier as regressors. Heteroskedasticity-consistent standard errors.

Source: Authors' tabulations of data from B'Tselem and Zussman and Zussman (2005) from 29 September 2000 to 30 April 2004. 
Table 12

The Effect of Border Closings, Checkpoints and Restrictions to Movement on the Palestinian Reaction Function

\begin{tabular}{|c|c|c|c|c|c|c|c|c|c|c|}
\hline & \multicolumn{2}{|c|}{$(1)$} & \multirow{2}{*}{\multicolumn{2}{|c|}{$(2)$}} & \multicolumn{2}{|c|}{$(3)$} & \multicolumn{2}{|c|}{ (4) } & \multicolumn{2}{|c|}{ (5) } \\
\hline & \multicolumn{8}{|c|}{ Dependent Variable: } & & \\
\hline & \multicolumn{2}{|c|}{$\begin{array}{c}\text { Fraction } \\
\text { checkpoints closed }\end{array}$} & \multicolumn{2}{|c|}{$\begin{array}{c}\text { Incidence: } \\
\text { Any Israeli } \\
\text { fatalities }\end{array}$} & \multicolumn{2}{|c|}{$\begin{array}{c}\text { Incidence: } \\
\text { Any Israeli } \\
\text { fatalities }\end{array}$} & \multicolumn{2}{|c|}{$\begin{array}{c}\text { Levels: Num. } \\
\text { of Israeli } \\
\text { fatalities }\end{array}$} & \multicolumn{2}{|c|}{$\begin{array}{c}\text { Levels: Num. } \\
\text { of Israeli } \\
\text { fatalities }\end{array}$} \\
\hline & Coef. & S.E. & Coef. & S.E. & Coef. & S.E. & Coef. & S.E. & Coef. & S.E. \\
\hline \multicolumn{11}{|l|}{ Number of days with Palestinian fatalities in days: } \\
\hline$t-1$ to $t-7$ & & & .012 & .011 & .010 & .011 & & & & \\
\hline$t-8$ to $t-14$ & & & .015 & .012 & .014 & .012 & & & & \\
\hline \multicolumn{11}{|l|}{ Number of days with Israeli fatalities in days: } \\
\hline$t-1$ to $t-7$ & & & .008 & .018 & .005 & .018 & & & & \\
\hline$t-8$ to $t-14$ & & & -.043 & .021 & -.047 & .021 & & & & \\
\hline \multicolumn{11}{|l|}{ Number of Palestinian fatalities in days: } \\
\hline$t-1$ to $t-7$ & .00045 & .00015 & & & & & 0.001 & 0.004 & -0.001 & 0.004 \\
\hline$t-8$ to $t-14$ & .00088 & .00018 & & & & & -0.002 & 0.003 & -0.005 & 0.003 \\
\hline \multicolumn{11}{|l|}{ Number of Israeli fatalities in days: } \\
\hline$t-1$ to $t-7$ & .00385 & .00068 & & & & & -0.032 & 0.015 & -0.043 & 0.017 \\
\hline$t-8$ to $t-14$ & .00417 & .00070 & & & & & -0.030 & 0.011 & -0.042 & 0.013 \\
\hline Fraction checkpoints closed & & & & & .374 & .281 & & & 2.946 & 1.097 \\
\hline$\chi^{2}$ for joint sig. of Palestinian fatalities ( $p$-value) & 39.07 & $(<.001)$ & 2.78 & $(.249)$ & 2.25 & $(.325)$ & 0.68 & $(.713)$ & 3.08 & $(.214)$ \\
\hline$\chi^{2}$ for joint sig. of Israeli fatalities ( $p$-value) & 57.65 & $(<.001)$ & 5.16 & $(.076)$ & 5.71 & $(.057)$ & 7.00 & $(.030)$ & 10.72 & $(.005)$ \\
\hline$R^{2}$ & \multicolumn{2}{|c|}{.251} & \multicolumn{2}{|c|}{.025} & \multicolumn{2}{|c|}{.029} & \multicolumn{2}{|c|}{.021} & \multicolumn{2}{|c|}{.029} \\
\hline
\end{tabular}

Note: All models estimated with ordinary least squares and include day-of-week indicators as well as the length of the separation barrier as regressors. Heteroskedasticity-consistent standard errors.

Source: Authors' tabulations of data from B'Tselem from 1 October 2003 to 15 January 2005. 


\section{Appendix: Numeric Codes for Checkpoint Status}

The verbal reports of OCHA were transformed into a numeric scale as follows:

1- Checkpoint closed

2- Open only for permit holders, Palestinians with Jerusalem ID, international citizens, UN representatives, etc.

3- Open only for residents of some villages, cities or for workers and traders with permits.

4- Open, but there is some restriction on age, hours of opening, or there are searches and long delays.

5- Open without restrictions.

The following table gives some examples of how the verbal reports were transformed into a numeric scale for one specific checkpoint on selected dates.

\begin{tabular}{|c|c|c|c|}
\hline Checkpoint & Date & Description & Code \\
\hline $\begin{array}{l}\text { Beit Jala DCO } \\
\text { Entrance to Beit Jala, } \\
\text { Bethlehem District }\end{array}$ & $20-26$ October 2004 & $\begin{array}{l}\text { Open from } 7 \mathrm{am} \text { to } 7 \mathrm{pm} \text { for all traffic. Palestinian public and private vehicles are allowed } \\
\text { to pass. Buses of Hebron national bus company and commercial trucks are not allowed to } \\
\text { cross: the buses drop off passengers at the Al Khadr - Husan junction. On } 25 \text { and } 26 \\
\text { October, it was open for } 24 \text { hours due to the closure of Gilo checkpoint. Delays were } \\
\text { experienced for vehicles going out of Bethlehem. }\end{array}$ & $\begin{array}{l}5 \text { on October } 25 \text { and } 26 \\
4 \text { on all other days. }\end{array}$ \\
\hline $\begin{array}{l}\text { Beit Jala DCO } \\
\text { Entrance to Beit Jala, } \\
\text { Bethlehem District }\end{array}$ & 4-10 August 2004 & $\begin{array}{l}\text { Open 7am to } 7 \mathrm{pm} \text { for all traffic. Palestinian public and private vehicles are allowed to } \\
\text { pass. Only buses of Hebron national bus company are not allowed to cross. Long queues } \\
\text { and delays were experienced for the vehicles coming out of Bethlehem. }\end{array}$ & 4 on all days. \\
\hline $\begin{array}{l}\text { Beit Jala DCO } \\
\text { Entrance to Beit Jala, } \\
\text { Bethlehem District }\end{array}$ & $\begin{array}{l}28 \text { July } 2004- \\
\text { August } 32004\end{array}$ & $\begin{array}{l}\text { Open from 07:00 - 19:00 for all traffic. Palestinian public and private vehicles are } \\
\text { allowed to pass. Only buses of Hebron national bus company are not allowed to cross. } \\
\text { Long queues and delays were experienced for the vehicles coming out of Bethlehem. On } \\
2 \text { August it was closed due to hot security warnings. }\end{array}$ & $\begin{array}{l}1 \text { on } 2 \text { August, } \\
4 \text { on all other days }\end{array}$ \\
\hline $\begin{array}{l}\text { Beit Jala DCO } \\
\text { Entrance to Beit Jala, } \\
\text { Bethlehem District }\end{array}$ & 9-15 June 2004 & $\begin{array}{l}\text { On } 13 \text { June the checkpoint was opened for all traffic, after being closed since } 3 \text { March } \\
\text { 2004. Palestinian vehicles need permits to cross. Buses of Hebron national bus company } \\
\text { are not allowed to cross. }\end{array}$ & $\begin{array}{l}1 \text { on } 9-12 \text { June } \\
3 \text { on } 13-15 \text { June }\end{array}$ \\
\hline $\begin{array}{l}\text { Beit Jala DCO } \\
\text { Entrance to Beit Jala, } \\
\text { Bethlehem District }\end{array}$ & $\begin{array}{l}22 \text { February } 2004- \\
16 \text { March } 2004\end{array}$ & $\begin{array}{l}\text { Reopened on } 25 \text { February following complete closure after } 22 \text { Feb. Closing time at 19:00 } \\
\text { hindering ability of medical services to carry out emergency assistance in all villages to } \\
\text { the west of Bethlehem after this time. Closed since } 03 \text { March. }\end{array}$ & $\begin{array}{l}1 \text { on } 22-24 \text { February } \\
4 \text { on } 25 \text { February - March } 2 \\
1 \text { on March 3- March } 16\end{array}$ \\
\hline $\begin{array}{l}\text { Beit Jala DCO } \\
\text { Entrance to Beit Jala, } \\
\text { Bethlehem District }\end{array}$ & 3-9 December 2003 & Open 7:00 to $19: 00$ hours to internationals and Palestinians with permits. & 2 on all days. \\
\hline
\end{tabular}

